\title{
Novel Substrates for Kinases Involved in the Biosynthesis of Inositol Pyrophosphates and Their Enhancement of ATPase Activity of a Kinase
}

\author{
Raja Mohanrao ${ }^{1}\left(\mathbb{D}\right.$, Ruth Manorama ${ }^{2}$, Shubhra Ganguli ${ }^{2,3}$, Mithun C. Madhusudhanan ${ }^{1}\left(\mathbb{D}\right.$, Rashna Bhandari ${ }^{2, *} * \mathbb{D}$ \\ and Kana M. Sureshan $1, *$ (D) \\ 1 School of Chemistry, Indian Institute of Science Education and Research Thiruvananthapuram, \\ Kerala 695551, India; rajamohanrao1@gmail.com (R.M.); mithun716@iisertvm.ac.in (M.C.M.) \\ 2 Laboratory of Cell Signalling, Centre for DNA Fingerprinting and Diagnostics, Hyderabad 500039, India; \\ manorama@cdfd.org.in (R.M.); shubhraganguli@cdfd.org.in (S.G.) \\ 3 Manipal Academy of Higher Education, Manipal 576104, India \\ * Correspondence: rashna@cdfd.org.in (R.B.); kms@iisertvm.ac.in (K.M.S.)
}

Citation: Mohanrao, R.;

Manorama, R.; Ganguli, S.;

Madhusudhanan, M.C.; Bhandari, R.;

Sureshan, K.M. Novel Substrates for

Kinases Involved in the Biosynthesis

of Inositol Pyrophosphates and Their

Enhancement of ATPase Activity of a

Kinase. Molecules 2021, 26, 3601.

https://doi.org/10.3390/

molecules 26123601

Academic Editors: Brullo Chiara,

Marie Migaud and Gerd Wagner

Received: 6 May 2021

Accepted: 7 June 2021

Published: 11 June 2021

Publisher's Note: MDPI stays neutral with regard to jurisdictional claims in published maps and institutional affiliations.

Copyright: (c) 2021 by the authors. Licensee MDPI, Basel, Switzerland. This article is an open access article distributed under the terms and conditions of the Creative Commons Attribution (CC BY) license (https:/ / creativecommons.org/licenses/by/ $4.0 /)$.

\begin{abstract}
IP6K and PPIP5K are two kinases involved in the synthesis of inositol pyrophosphates. Synthetic analogs or mimics are necessary to understand the substrate specificity of these enzymes and to find molecules that can alter inositol pyrophosphate synthesis. In this context, we synthesized four scyllo-inositol polyphosphates-scyllo- $\mathrm{IP}_{5}$, scyllo- $\mathrm{IP}_{6}$, scyllo- $\mathrm{IP}_{7}$ and Bz-scyllo- $\mathrm{IP}_{5}$ - from myo-inositol and studied their activity as substrates for mouse IP6K1 and the catalytic domain of VIP1, the budding yeast variant of PPIP5K. We incubated these scyllo-inositol polyphosphates with these kinases and ATP as the phosphate donor. We tracked enzyme activity by measuring the amount of radiolabeled scyllo-inositol pyrophosphate product formed and the amount of ATP consumed. All scyllo-inositol polyphosphates are substrates for both the kinases but they are weaker than the corresponding myo-inositol phosphate. Our study reveals the importance of axial-hydroxyl/phosphate for IP6K1 substrate recognition. We found that all these derivatives enhance the ATPase activity of VIP1. We found very weak ligand-induced ATPase activity for IP6K1. Benzoyl-scyllo-IP 5 was the most potent ligand to induce IP6K1 ATPase activity despite being a weak substrate. This compound could have potential as a competitive inhibitor.
\end{abstract}

Keywords: kinase; inositol pyrophosphate; IP6K1; VIP1 KD; ATPase

\section{Introduction}

Phosphoinositols play a variety of roles in cellular signaling [1,2]. Diphospho-inositol polyphosphates (PPIPns) are a class of highly phosphorylated myo-inositol derivatives that have one or two pyrophosphate moieties and occur only in eukaryotes [3-5]. PPIPns present in mammals include 5-PP-IP 4 , 5-PP-IP 5 , 1-PP-IP 5 and 1,5-[PP $]_{2}-\mathrm{IP}_{4}$, and their cellular levels are regulated by (i) IP6Ks, kinases which pyrophosphorylate the 5-position of myo-inositol, (ii) PPIP5Ks, kinases which pyrophosphorylate the 1-position and (iii) DIPPs, phosphatases which dephosphorylate the pyrophosphate to phosphate (Figure 1A) [6-8]. PPIPns play vital roles in apoptosis, cellular signaling, vesicular trafficking, metabolic homeostasis, cytoskeletal dynamics, exocytosis, insulin signaling, DNA damage repair, telomere maintenance, stress response, etc. [4,9-24]. Clear mechanisms of their wide-ranging functions are yet to be ascertained [23,25-27]. For biochemical and genetic exploration to unravel the structure-activity relationships (SAR) and mechanism of their actions, it is necessary to synthesize these molecules and their analogs [2,22,28-30]. Recently, Jessen et al. reported elegant approaches to synthesize various PPIPn analogs [31-33]. These analogs served as tools to unravel various biological roles played by inositol pyrophosphates [34]. Potter et al. [35] and Fiedler et al. [29,36,37] independently synthesized PPIPn analogs 
having non-hydrolyzable pyrophosphate surrogates and established, through biochemical assays, that this modification does not prevent target recognition and action of metabolizing enzymes. Both of these studies have also established that the recognizing enzymes can tolerate 2-O-substitution with a hydrophobic group. An extension of this study not only validated the previously reported [38] ligand induced ATPase activity of one of the kinases, PPIP5K2, but also unraveled the mechanism for the same [39]. Here we report the syntheses and biochemical studies of four novel substrate analogs of kinases involved in PPIPn biosynthesis, and ATPase activities of both these kinases.

A
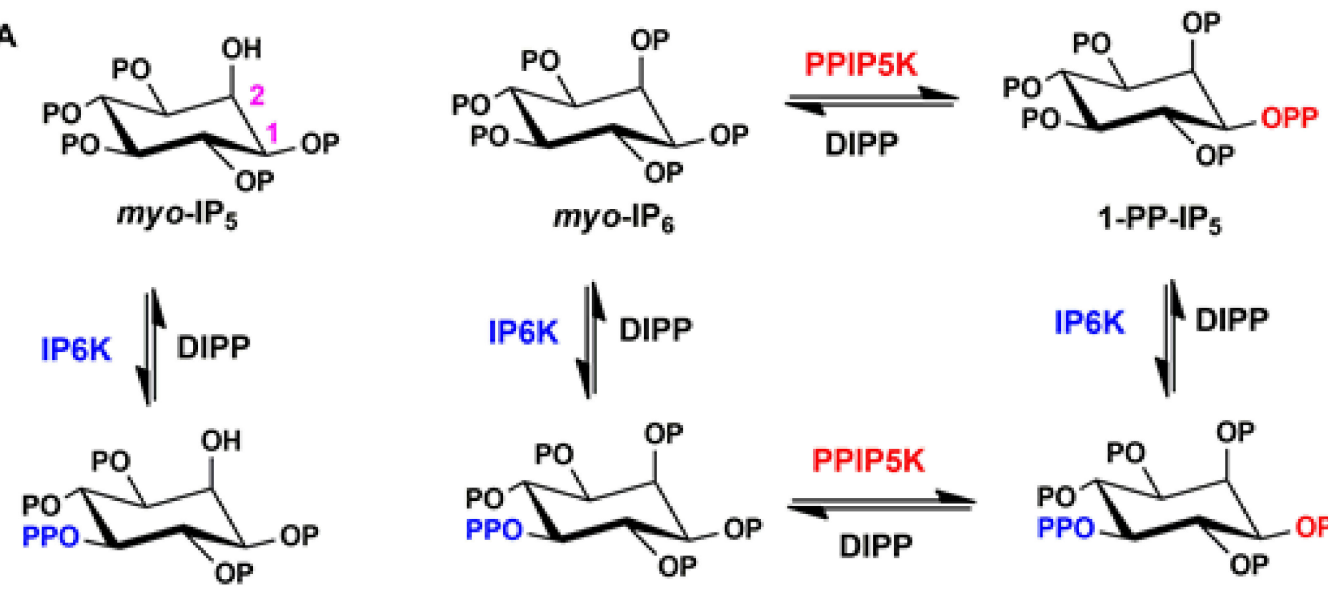

5-PP-IP 4

5-PP-IP 5
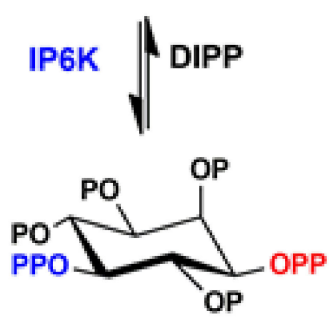

$1,5-[\mathrm{PP}]_{2}-\mathrm{IP}_{4}$

B
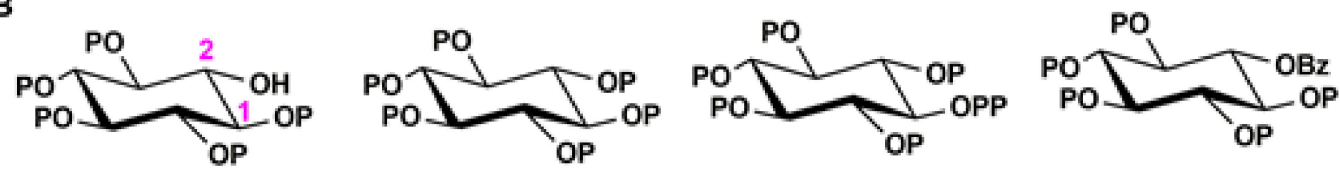

scyllo-IP

scyllo-IP $\mathrm{P}_{6}$

scyllo-IP

Bz-scyllo-IP 5<smiles>O=P([O-])([O-])[PH]#P</smiles><smiles>CP(=O)([O-])OP(=O)([O-])[O-]</smiles>

Figure 1. (A) Biosynthesis of inositol pyrophosphates in mammalian cells. (B) Proposed ligands to probe kinase activity.

As mentioned earlier, IP6Ks and PPIP5Ks are involved in the biosynthesis of PPIPns. $\mathrm{IP}_{5}, \mathrm{IP}_{6}$ and 1-PP-IP $\mathrm{IP}_{5}$ are the natural substrates for IP6Ks and get phosphorylated to 5-PP-IP 4 , 5-PP-IP 5 and 1,5-[PP $]_{2}-\mathrm{IP}_{4}$, respectively (Figure 1A). Similarly, $\mathrm{IP}_{6}$ and 5-PP- $\mathrm{IP}_{5}$ are the natural substrates for PPIP5Ks and get phosphorylated to 1-PP-IP 5 and 1,5-[PP] $]_{2}-\mathrm{IP}_{4}$, respectively (Figure 1A) [40-43]. There is great interest in understanding the mechanism, function and substrate-specificity of these enzymes using various analogs as synthetic tools $[30,35,36,39,44]$. An important strategy to make analogs of IPns is to alter the inositol core. We chose scyllo-inositol, the C2-epimer of myo-inositol as the central core to synthesize PPIPn analogs. Scyllo-inositol phosphates constitute the second naturally abundant inositol phosphates [45-47] and many scyllo-inositol phosphates have been found in living organisms and in the environment [48,49]. Utilizing these scyllo-inositol phosphates as substrates for the PPIPn synthesizing kinases, would provide valuable information regarding enzyme function. In this context, we planned to synthesize scyllo- $\mathrm{IP}_{5}$, scyllo- $\mathrm{IP}_{6}$ and scyllo- $\mathrm{IP}_{7}$ (Figure 1B) to test them as substrates for Vip1 (budding yeast $\mathrm{S}$. cerevisiae ortholog of PPIP5K) and mouse IP6K1. While the first two are mimics of $\mathrm{IP}_{5}$ and $\mathrm{IP}_{6}$ 
respectively, scyllo- $\mathrm{IP}_{7}$ is a mimic of both 1-PP- $\mathrm{IP}_{5}$ and 5-PP- $\mathrm{IP}_{5}$. We also planned to synthesize $\mathrm{Bz}$-scyllo-IP ${ }_{5}$, as 2-O-benzyl/2-O-benzoyl substituted ligands are known to activate PPIP5K2 [39].

\section{Results and Discussion}

\subsection{Synthesis of Scyllo-Inositol Phosphates}

Scyllo-inositol derivative $\mathbf{1}$ was synthesized from myo-inositol in four steps by following the reported procedure [45]. Acidic hydrolysis of $\mathbf{1}$ with $1 \mathrm{~N} \mathrm{HCl}$ in ethanol yielded scyllo-inositol (2), which, on phosphitylation with $\mathrm{N}, \mathrm{N}$-dibenzyl diisopropylphosphoramidite in the presence of $1 \mathrm{H}$-tetrazole followed by oxidation with $m$-CPBA at $-78^{\circ} \mathrm{C}$, gave hexaphosphorylated scyllo-inositol derivative 3 (Scheme 1). Hydrogenolysis of 3 yielded scyllo- $\mathrm{IP}_{6}(\mathbf{4})$. Benzoylation of $\mathbf{1}$ followed by acidic hydrolysis of the ester $\mathbf{5}$ gave benzoyl-scyllo-inositol (6). Phosphorylation of $\mathbf{6}$ resulted in the fully protected scyllo-inositol pentakisphosphate (7), which, on hydrogenolysis, yielded the benzoyl-scyllo- $\mathrm{IP}_{5}(\mathbf{8})$. Compound 8 on treatment with $1 \mathrm{~N} \mathrm{LiOH}$ gave scyllo- $\mathrm{IP}_{5}(9)$, which was purified by passing through Dowex $\mathrm{H}^{+}$resin.
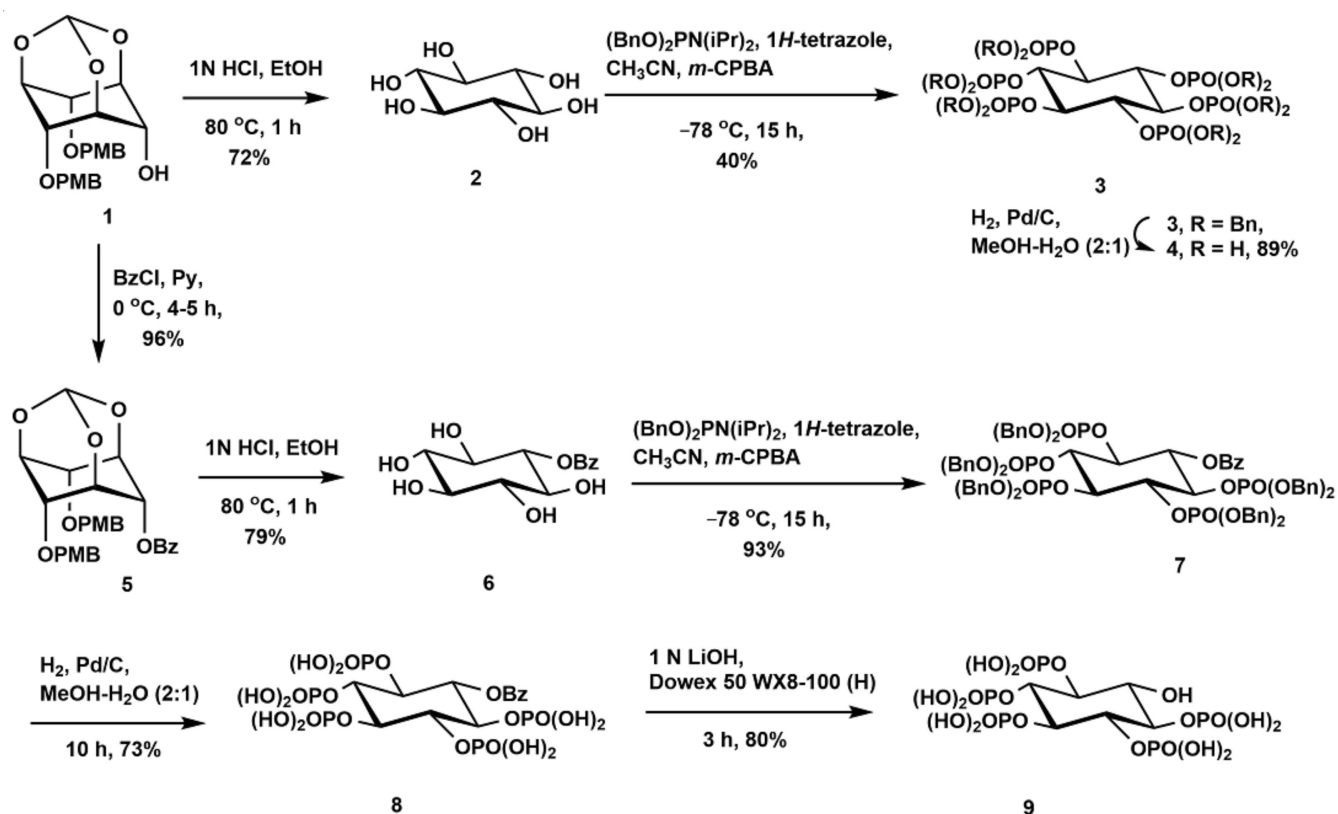

Scheme 1. Synthesis of scyllo- $\mathrm{IP}_{6}(4), \mathrm{Bz}-s c y l l o-\mathrm{IP}_{5}(8)$ and scyllo-IP 5 (9).

Next, we turned our attention to synthesize scyllo-IP 7 (Scheme 2). Attempts to remove the benzoyl group selectively from compound 7 failed. This prompted us to pursue another approach for the synthesis of scyllo-IP 7 (20) starting from myo-inositol derivative 10 [50]. Selective $O$-alkylation of the equatorial hydroxyl group using $p$-methoxybenzyl chloride gave compound 11, which, on triflylation, gave the triflate 12. Nucleophilic displacement of the trifllate with acetate gave scyllo-inositol derivative 13, which, on saponification, yielded the pentol 14. Phosphitylation of pentol $\mathbf{1 4}$ followed by in situ oxidation resulted in the formation of fully protected pentakisphosphate 15 . Oxidative removal of the PMB group afforded compound 16, whose structure was unambiguously confirmed by single crystal XRD analysis (see Figure 7 in Section 3.2.15., Crystal Data for 16). Compound 16 was then phosphitylated with the unsymmetrical phosphoramidate, 2-cyanoethyl- $N, N$-diisopropyl benzylphosphoramidte (see Scheme 3 in Section 3.2.16.), followed by oxidation to get differently protected hexakisphosphate derivative 17 . Deprotection of the cyanoethyl group gave the phosphodiester 18. Phosphorylation of $\mathbf{1 8}$ using dibenzylphosphoryl chloride $[30,51]$ yielded fully protected scyllo- $\mathrm{IP}_{7}$ derivative $\mathbf{1 9}$, which was used without purification for hydrogenolysis to get the scyllo-IP 7 (20). 

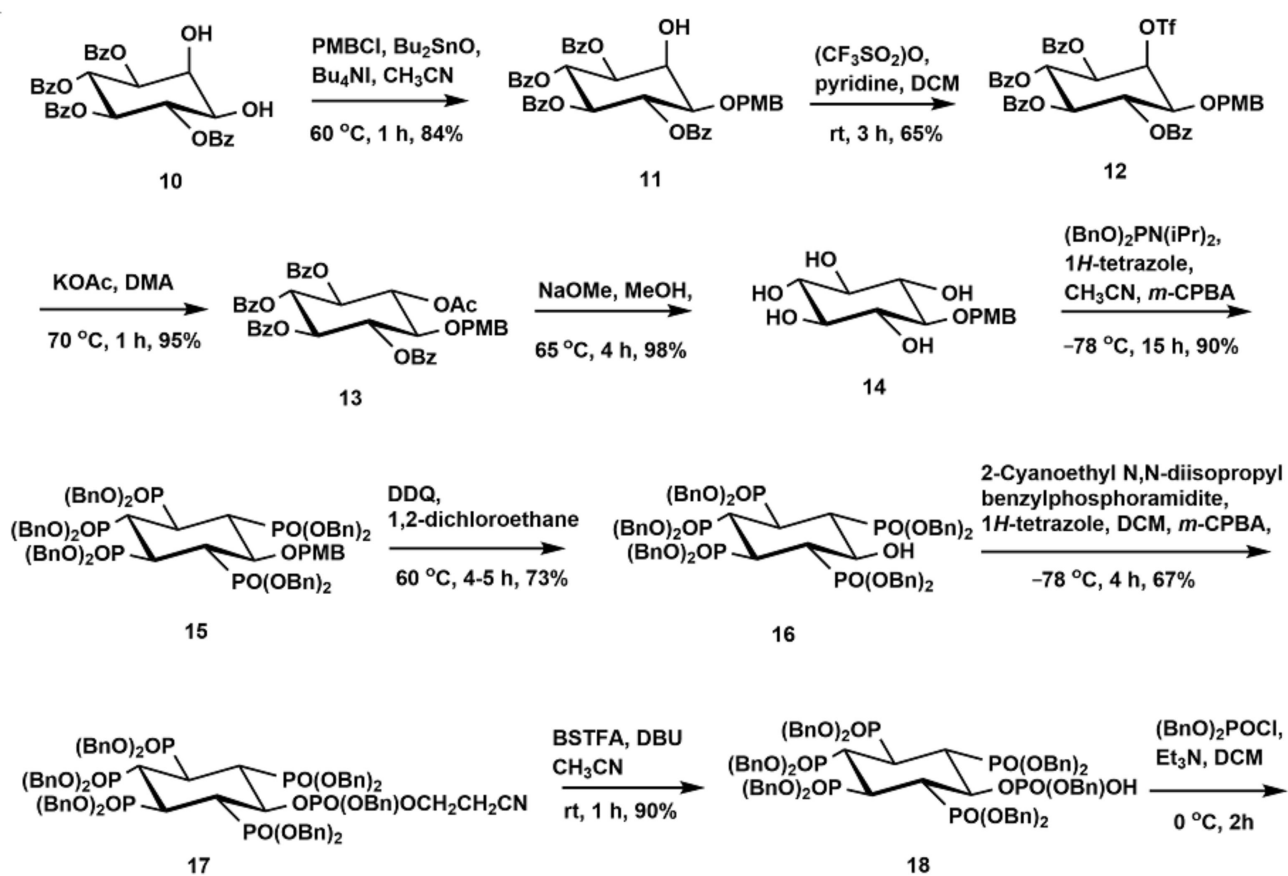

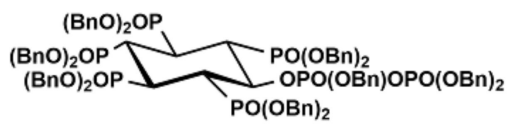

19

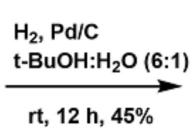

rt, 12 h, $45 \%$

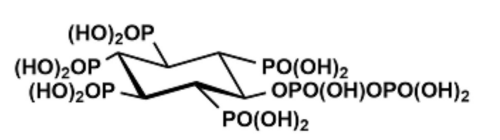

20, scyllo-IP

Scheme 2. Synthesis of scyllo- $\mathrm{IP}_{7}$ (20).

\subsection{Analysis of Scyllo-Inositol Phosphates as Substrates for IP6K and PPIP5K}

We investigated the ability of these scyllo-inositol phosphates to act as substrates for mouse IP6K1 (UniProt entry Q6PD10) and S. cerevisiae VIP1 (UniProt entry Q06685) in comparison with myo-IP ${ }_{5}$ and $\mathrm{IP}_{6}$. All these substrate analogs were incubated with ATP and purified $N$-terminally $6 x$ His-tagged mouse IP6K1 or the kinase domain (amino acid residues 1-535) of S. cerevisiae VIP1 fused N-terminally to GST (VIP1-KD). The IPn substrates and their PPIPn products were resolved by polyacrylamide gel electrophoresis (PAGE) and detected by staining with toluidine blue dye (Section 3.3). Upon the incubation of $m y 0-\mathrm{IP}_{5}$ or $m y o-\mathrm{IP}_{6}$ with IP6K1 or VIP1-KD, we detected one or more myo-PPIPn products (Supplementary Figure S1). Our observations are in concordance with an earlier report demonstrating multiple PP-IP products arising from the action of these IP kinases on myo$\mathrm{IP}_{5}$ or $m y 0-\mathrm{IP}_{6}$, many of which are uncharacterized [52]. All scyllo-IPns served as substrates for both IP6K1 and VIP1-KD (Supplementary Figure S1). PAGE analysis of PP-IPs is not suitable for the quantitative comparison of scyllo- vs. myo-IPs as substrates, owing to the variation in staining of different IPns by toluidine blue dye. Therefore, to quantify the PPIPn products arising from myo- and scyllo-IPn substrates, we resorted to the use of radiolabeled ATP. Equimolar quantities of the different IPn substrates were incubated with either enzyme in the presence of $\left[\gamma_{-}{ }^{32} \mathrm{P}\right] \mathrm{ATP}$; the enzymatic reactions were quenched by adding perchloric acid and then neutralized with potassium carbonate and EDTA (Section 3.3). The products were separated by strong anion exchange HPLC, and $1 \mathrm{~mL}$ fractions were collected and counted using a liquid scintillation counter. The substrates and the corresponding chromatograms showing the peaks due to phosphorylated products are shown in Figure 2. Each HPLC peak represents the addition of a radiolabeled phosphate onto the IPn substrate. Owing to the inability to use an ATP regeneration system along with radiolabeled ATP (see Section 3.3), in many cases, we observed fewer products by HPLC compared with PAGE analysis. 

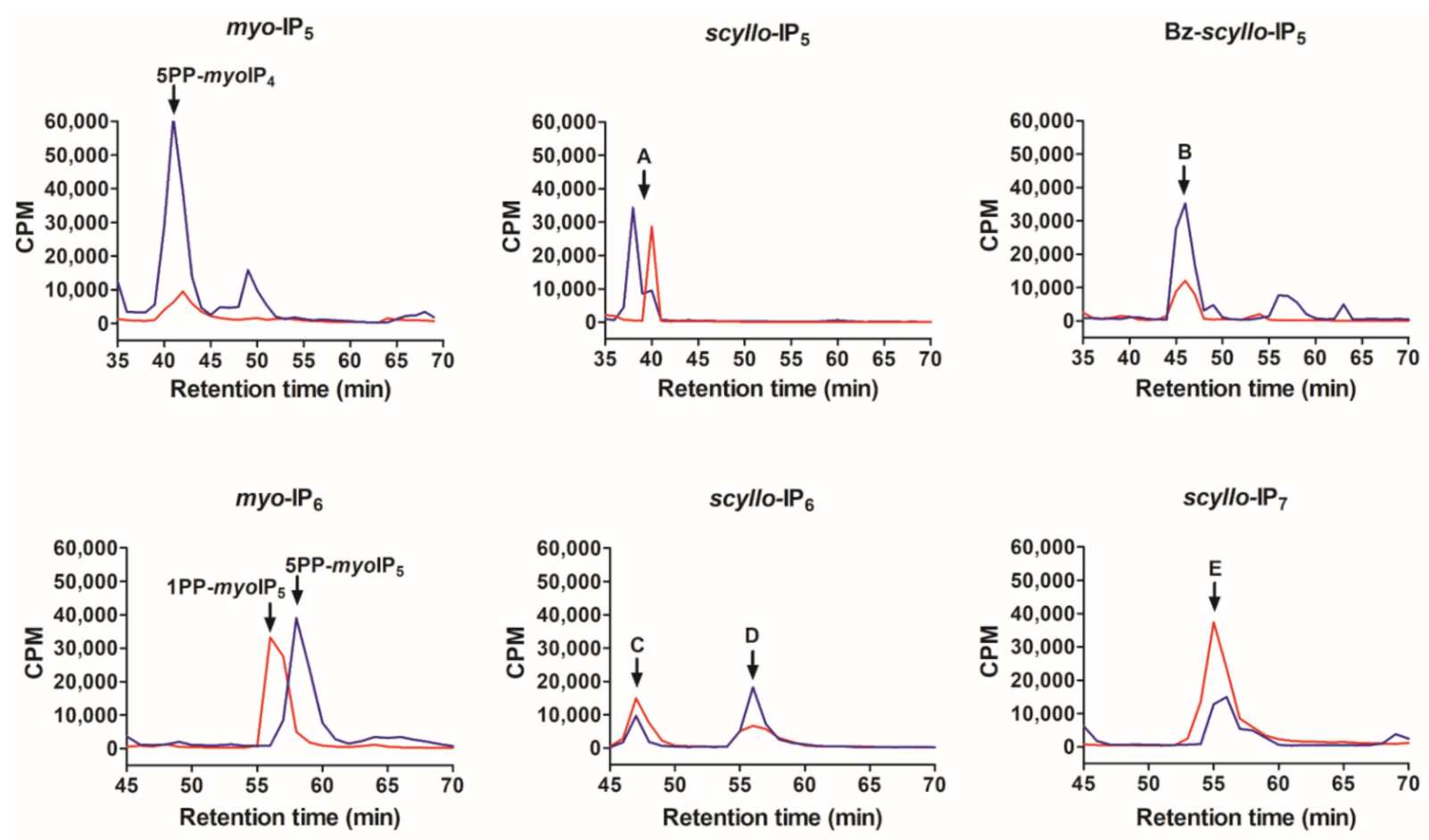

Figure 2. Chromatograms of the phosphorylated PPIPn products (indicated by arrows) formed by the catalysis of IP6K1 (blue) and VIP1-KD (red) on various IPn substrates. The IPn substrate used in each case is indicated above the chromatogram. The reaction products were resolved by strong anion exchange HPLC as described in Section 3.3. Retention times for standard myo-IPs were marked using radiolabeled inositol phosphates extracted from budding yeast (Section 3.3 and Supplementary Figure S2B). The traces represent one of four independent experiments. The well-characterized products of $m y o-\mathrm{IP}_{5}$ and $m y o-\mathrm{IP}_{6}$ are indicated. The PPIPn products of scyllo-IPs are likely to be as follows: A. PP-scyllo-IP 4 B. PP-Bz-scyllo-IP $\mathrm{IP}_{4}$ C. PP-scyllo-IP 5 ; D. $[\mathrm{PP}]_{2}$-scyllo-IP $4 /$ PPP-scyllo-IP 5 ; E. $[\mathrm{PP}]_{2}$-scyllo-IP $4 / \mathrm{PPP}-$ scyllo-IP $_{5}$. The corresponding PPIPn products observed by PAGE analysis are similarly annotated in Figure S1. See Figure S2B,C for chromatograms of other myo-IPn and myo-PPIPn standards, and ATP, under the same conditions.

We have proposed probable structures for the scyllo-PPIPn products seen by gel electrophoresis and HPLC (see legends for Figure 2 and Supplementary Figure S1). Our proposed structures are based on the known catalytic properties of IP6K1 and VIP1 towards myo-inositol substrates. IP6K1 catalyzes the addition of a $\beta$-phosphate onto an $\alpha$-phosphate, and a $\gamma$-phosphate onto a $\beta$-phosphate on $\mathrm{C}_{5}$ of $m y o-\mathrm{IP}_{5}$ and $m y o-\mathrm{IP}_{6}[19,53]$, whereas VIP1 acts to add a $\beta$-phosphate on $\mathrm{C} 1$ of myo- $\mathrm{IP}_{6}$ and myo-IP 7 [13,17]. As all equatorial carbon atoms of scyllo-inositol are indistinguishable from each other, we propose that the same scyllo-PPIPn products arise by the action of both enzymes. Therefore, IP6K1

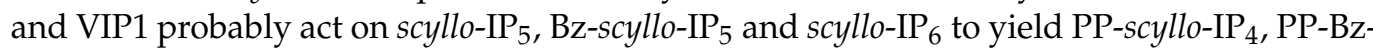
scyllo- $\mathrm{IP}_{4}$ and PP-scyllo-IP 5 (i.e., scyllo-IP $\mathrm{IP}_{7}$ ), respectively (peaks A, B and C in Figure 2). The product formed by the addition of two phosphates onto scyllo-IP 6 (peak D), and one phosphate onto scyllo- $\mathrm{IP}_{7}$ (peak E), are likely to correspond to a scyllo-inositol with 8 phosphate groups. This could be $[\mathrm{PP}]_{2}$-scyllo-IP $\mathrm{I}_{4}$ or PPP-scyllo-IP ${ }_{5}$. The only unambiguous means of identifying the structures of any of the scyllo-PPIPn products is via NMR. However, it is not trivial to obtain sufficient quantities of purified, enzymatically synthesized PPIPn products required for such an analysis. The masses of the products we have proposed are based on the bands visualized by PAGE (separated by a single phosphate units), and the resolution of ${ }^{32} \mathrm{P}$-labeled inositol phosphates by HPLC. Despite repeated attempts we were unable to detect enzymatically synthesized scyllo-PPIPn products by mass spectrometryHPLC-purified radiolabeled products cannot be loaded onto a mass spectrometer due to radiation safety protocols, and contaminating substances from polyacrylamide gels interfered with our attempts to analyze gel-eluted scyllo-IPs. For the above reasons, the 
proposed structures of the scyllo-PPIPn products detected by PAGE and HPLC analysis are likely, but not certain.

Analysis of the conversion of the substrates to products indicates that all scyllo-IPns tested are substrates for IP6K1, but they are relatively poorer substrates than the corresponding myo-inositol phosphates (Figure 3A). For IP6K1, myo- $\mathrm{IP}_{5}$ shows the best conversion rate and is approximately 1.5 -fold the conversion rate of $m y o-\mathrm{IP}_{6}$. This is in agreement with the trend reported previously [53]. Interestingly, scyllo- $\mathrm{IP}_{5}$ and scyllo- $\mathrm{IP}_{6}$ are poor substrates for IP6K1 compared with their myo-counterparts. This suggests that an axial C2-hydroxyl/phosphate has an important role in active-site binding. This requirement was however partially offset by the presence of a benzoyl group on scyllo-IP $\mathrm{I}_{5}$. It has been shown that IP6K1 can act on 5PP-myo-IP 5 to generate a triphosphate containing species5PPP-myo-IP 5 [19]. We observed that IP6K1 can also act on scyllo-IP 7 to generate a product (Figure 2, peak E), which possibly contains a triphosphate moiety.

A

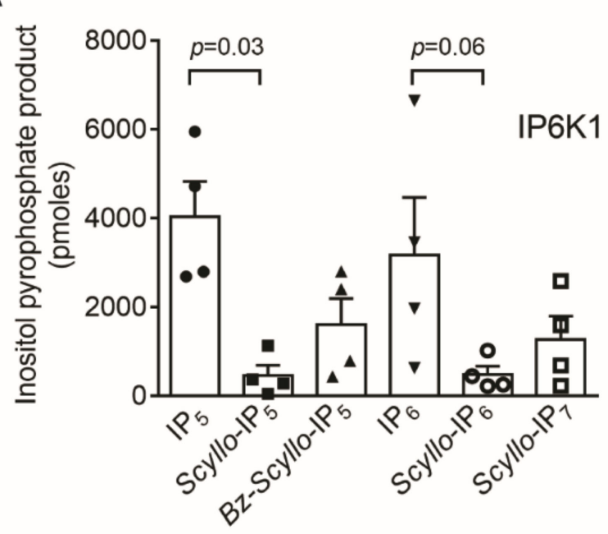

$\mathrm{B}$

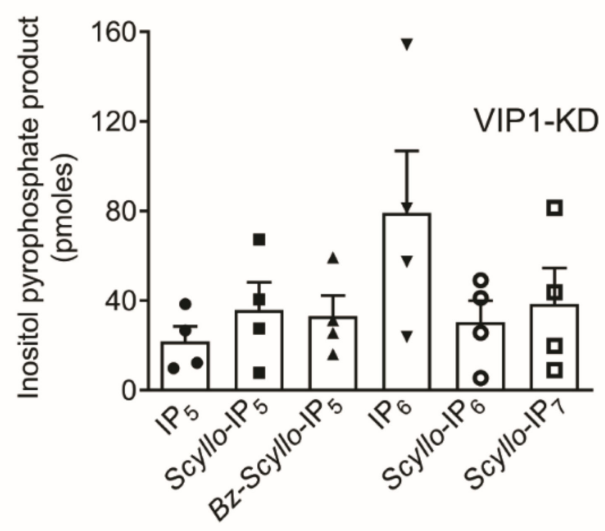

Figure 3. Extent of conversion of the substrates to products by (A) IP6K1 in presence of ATP $(1 \mathrm{mM})$ and IPn $(200 \mu \mathrm{M})$. (B) VIP1-KD in presence of ATP $(40 \mu \mathrm{M})$ and IPn $(100 \mu \mathrm{M})$. PPIPn product formation was calculated as described in Section 3.3. The graphs show individual data points and mean \pm SEM from four independent experiments. Data was analyzed using a two-tailed Mann-Whitney test to compare the PPIPn product of myo-IPn with its corresponding scyllo-derivative. $p$ values are indicated where significant.

In contrast to IP6K1, all scyllo-IPns acted as moderate substrates for VIP1 (Figure 3B). $m y o-\mathrm{IP}_{5}$ is the poorest substrate of all those tested. This is in agreement with the fact that 1-PP-IP 4 has not been found in vivo and also with a previous report that $m y o-\mathrm{IP}_{5}$ is not a substrate for PPIP5Ks, mammalian orthologs of Vip1 [17]. myo- $\mathrm{IP}_{6}$ is the best substrate; the approximately 3 -fold difference between $m y o-\mathrm{IP}_{5}$ and $m y o-\mathrm{IP}_{6}$ phosphorylation by VIP1-KD suggests that the 2-phopshate is crucial for active site binding/effective phosphotransfer. All scyllo-IPns tested were weaker substrates for VIP1 compared with myo-IP ${ }_{6}$, although the difference was not statistically significant. This suggests that the loss of the axial C2-phosphate can be partially compensated by an equatorial phosphate at that position. Interestingly, the presence of a benzoyl group on scyllo-IP ${ }_{5}$ did not interfere with its ability to serve as a substrate for VIP1. It is to be noted that structurally similar 2-O-benzyl-myo-IP 5 was reported to be an inhibitor of PPIP5K but an activator of its ATPase activity [39].

In order to get further insights about the IPn-kinase interactions, we conducted molecular docking with the kinases and myo- $\mathrm{IP}_{6}$ and scyllo- $\mathrm{IP}_{6}$ as ligands using CCDC GOLD suit (see Supplementary Materials and Supplementary Figure S3). Since exact structures for ScVIP1 and IP6K1 are not available, the molecular docking experiments were carried out at the active sites of analogous hPPIP5K2 and IP6KA kinase of Entamoeba histolytica (PDB code: 3T9C, 4O4F) [17,54]. With both the enzymes, myo-IP 6 showed better fitness score than scyllo- $\mathrm{IP}_{6}$ and this is in agreement with the experimental observation of higher turnover for the myo-IPns. Furthermore, total number of attractive interactions between the enzyme and ligands was more for $m y o-\mathrm{IP}_{6}$ in both the cases. While $m y o-\mathrm{IP}_{6}$ had 
21 interactions with IP6K, the scyllo-isomer had only 17 interactions. Similarly, PPIP5K2 kinase domain had 28 interactions with the myo- $\mathrm{IP}_{6}$ and 26 interactions with the scylllo-IP 6 . Interestingly, the axial $\mathrm{C} 2$ phosphate in myo-IP 6 shows seven interactions with the IP6K side-chains (K101, R119, S207, T106, R134), but the corresponding equatorial phosphate in scyllo-IP 6 shows four interactions (R119, K118, R134, T106). In the case of PPIP5K2, the axial phosphate at C2 position shows seven interactions (K329, R262, K248, R281, Y250) and equatorial phosphate makes five interactions (K329, K248, R262, R281) (Figure 4). This difference in number and strength of such interactions can influence the substrate binding and, thus, the kinase activity.

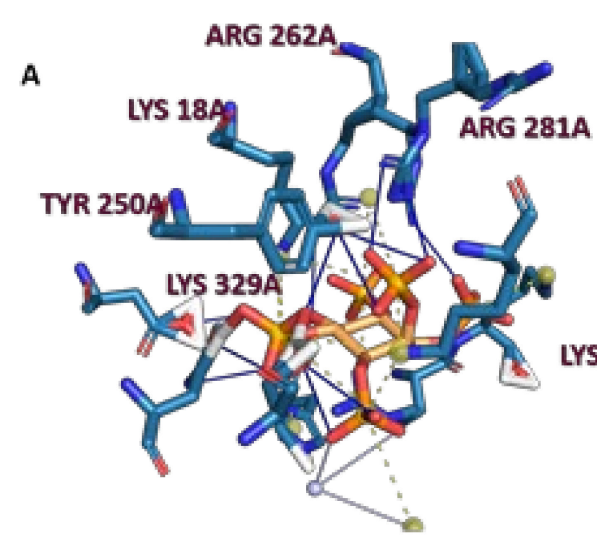

C
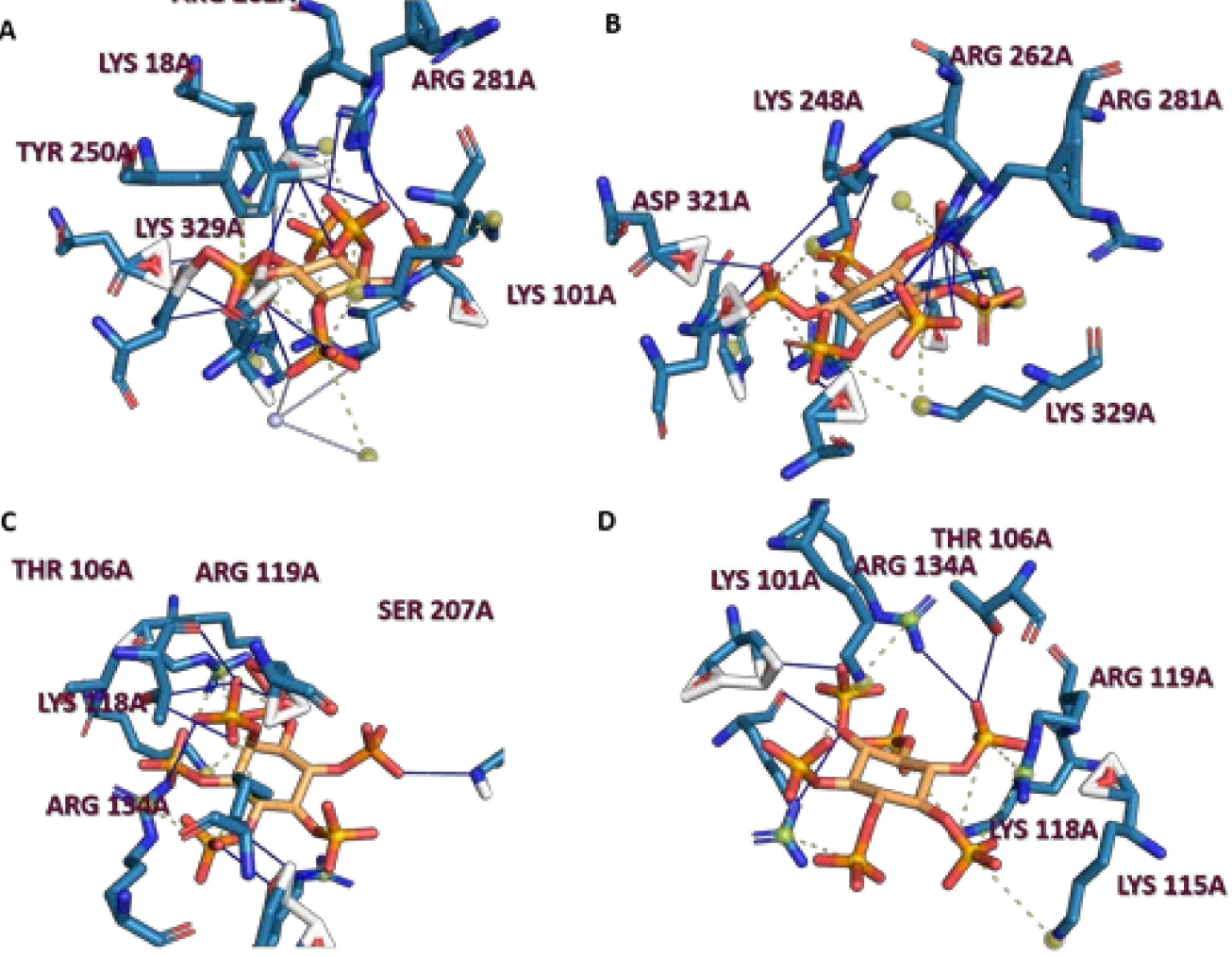

Figure 4. Molecular Docking results of myo and scyllo-IP 6 on PPIP5K2 and EhIP6KA (GOLDScore); (A) $m y o-\mathrm{IP}_{6}$ at the active site of PPIP5K2; (B) scyllo-IP 6 at the active site of PPIP5K2; (C) myo-IP 6 at the active site of EhIP6KA; (D) scyllo-IP 6 at the active site of EhIP6KA. All interactions were visualized using PLIP while further image processing was carried out using PyMOL [55].

The non-productive activation of PPIP5K2 by inositol phosphates leading to the hydrolysis of ATP to ADP (ATPase activity) has been reported [38]. Later, biochemical studies and mutagenesis studies, using several synthetic analogs, revealed the existence of a surface-exposed second binding site within the kinase domain of PPIP5K2, which acts as a capture site for the substrate, and that the natural substrate occupies this site only transiently before being delivered to the catalytic site [39]. The ATPase activity was found to be associated with ligand occupancy at the capture site. This study also found that 2-O-benzyl-myo- $\mathrm{IP}_{5}$ interacts weakly with the catalytic site but binds better at the capture site of PPIP5K2, and consequently it is not a substrate of this kinase but a ligand that induces its ATPase activity [39]. We were curious to investigate the ability of scyllo-inositol phosphates to induce the ATPase activity of VIP1. A recent report describing a highthroughput assay for IP6K1 activity suggested that measuring ADP production from ATP is an easier alternative to HPLC-based measurement of 5-PP-IP 5 produced from $\mathrm{IP}_{6}[56]$. By extension, PPIPn products of scyllo-IPs should also lead to concomitant ADP release from ATP, which can be used to measure kinase activity against these substrates. Furthermore, 
many kinases are known to possess inherent ATPase activity [57-63], and PPIP5K2 shows substrate-stimulated ATP hydrolysis $(38,39)$. With these considerations, we studied ADP production by both kinases, IP6K1 and VIP1-KD. We ruled out the presence of any contaminating ATPase or phosphatase in the preparation of 6xHis-mIP6K1 or GST-VIP1-KD purified from the E. coli expression system (see Section 3.4 and Supplementary Figure S4).

We used the ADP-GloTM kinase assay kit to monitor the conversion of ATP to ADP by IP6K1 and VIP1-KD in the presence of their IP substrates (Section 3.4) [56]. ADP-GloTM kinase assay is a luminescence detection assay method to measure the percentage of ATP that is converted to ADP during a kinase reaction. VIP1-KD showed considerable basal activity, converting close to $40 \%$ of the ATP supplied during the reaction to ADP (Figure 5A), which is in agreement with its known inherent ATPase activity [38]. In contrast to the stimulation of non-productive ATPase activity by $\mathrm{IP}_{5}$ and $\mathrm{IP}_{6}$ reported in the case of PPIP5K2 [38,39], in our hands, both $\mathrm{IP}_{5}$ and $\mathrm{IP}_{6}$ showed only negligible ATPase activation of VIP1 over the basal level (Figure 6A). This may be due to differences in the behavior of VIP1 and PPIP5K2. It may also be a reflection of the significantly lower levels of ATP used in our assay - at high concentrations of ATP (5-10 mM), the presence of $\mathrm{IP}_{5}$ and $\mathrm{IP}_{6}$ leads to a 2- to 4-fold elevation in the release of Pi from ATP by PPIP5K2 (38). Under physiological ATP concentrations, $\mathrm{IP}_{5}$ or $\mathrm{IP}_{6}$ may stimulate ATPase activity of the VIP1-KD; substrate-independent ATPase activity of VIP1-KD may also increase at physiological [ATP]. The $4-6 \%$ of ATP consumed in the presence of $\mathrm{IP}_{6}$ (Figure $6 \mathrm{~A}$ ) is sufficient for the conversion of approximately $2 \%$ of $\mathrm{IP}_{6}$ to $1-\mathrm{PP}_{-} \mathrm{IP}_{5}$, in agreement with the extent of product formation shown in Figure 3B. All the scyllo-IPns tested showed up to two-fold enhancement in ATPase activity of VIP1 (Figure 5A). Interestingly, scyllo- $\mathrm{IP}_{5}$ and scyllo-IP 6 enhance ATPase activity four times more than their corresponding myo-IPns (Figure 6A). This property of scyllo- $\mathrm{IP}_{5}$ and scyllo- $\mathrm{IP}_{6}$ to induce non-productive ATPase activity while being moderate substrates, suggests that these ligands may bind better at the capture site than the catalytic site of VIP1. Bz-scyllo- $\mathrm{IP}_{5}$ and scyllo- $\mathrm{IP}_{7}$ are also potent inducers of VIP1 ATPase activity; while the ATPase activity of the former is in agreement with the previously reported effect of 2-O-benzyl substituted myo- $\mathrm{IP}_{5}$ enhancing non-productive ATPase activity of PPIP5K2 [39], in case of the latter, the absence of an axial-phosphate group may weaken its interaction with the active site and thus increase its residence time at the capture site, stimulating futile ATPase activity.

A

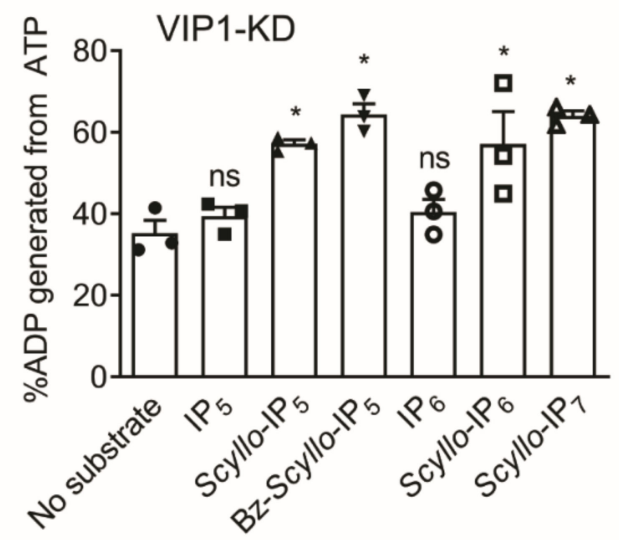

B

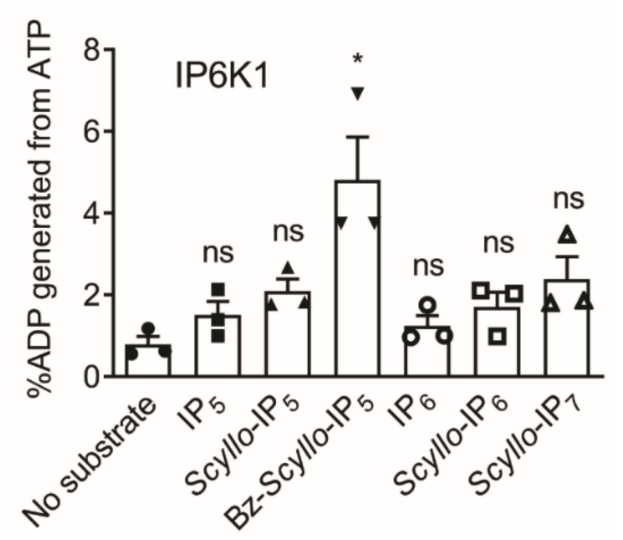

Figure 5. The effects of the myo- and scyllo-inositol phosphates upon ATPase activity of (A) VIP1-KD in presence of ATP $(40 \mu \mathrm{M})$ and IPn $(100 \mu \mathrm{M})$. (B) IP6K1 in presence of ATP $(1 \mathrm{mM})$ and IPn $(200 \mu \mathrm{M})$. The graphs show individual data points and mean \pm SEM from three independent experiments. Data was analyzed using one-way ANOVA to compare each condition with ATPase activity in the absence of substrate. ${ }^{*} p \leq 0.05$; ns, not significant, $p>0.05$. 
A

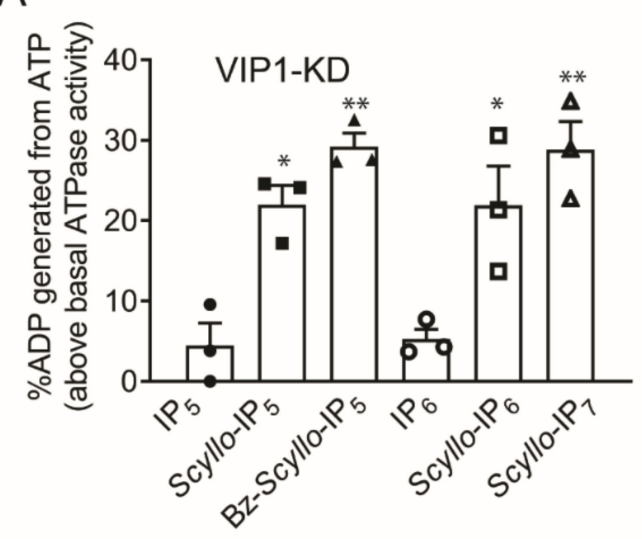

B

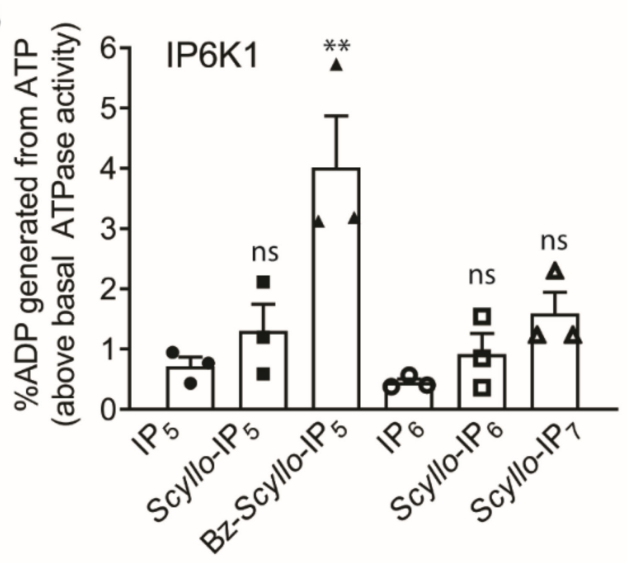

Figure 6. Percentage of ADP generated in the kinase reactions for (A) VIP1-KD and (B) IP6K1, after subtraction of basal ADP generated in the absence of substrate, for the data shown in Figure 5. The graphs show individual data points and mean \pm SEM from three independent experiments. Data was analyzed using one-way ANOVA to compare ATPase activity in the presence of each scyllo-IPn with ATPase activity in the presence of either $m y o-\mathrm{IP}_{5}$ or $m y o-\mathrm{IP}_{6}$ (which were not significantly different from each other). ${ }^{* *} p \leq 0.01 ;{ }^{*} p \leq 0.05$; ns, not significant, $p>0.05$.

IP6K1 showed a very low basal activity, suggesting that it is not an inherent ATPase (Figure 5B). The myo- and scyllo-inositol phosphates increased ADP production marginally (Figure 6B), in keeping with the transfer of the gamma phosphate from ATP to generate the corresponding inositol pyrophosphate (Figure 3A). An intriguing exception to this was Bz-scyllo- $\mathrm{IP}_{5}$, which yielded a low amount of inositol pyrophosphate product, but significantly stimulated ATPase activity in IP6K1. Further studies will be required to establish non-productive ATPase activity in IP6K1.

In conclusion, we synthesized a series of scyllo-inositol phosphates as substrates for the two kinases involved in diphosphoinositol polyphosphate synthesis. This study revealed the tolerance of these enzymes for the myo- to scyllo-isomers. The relative potentials of these compounds as substrates in comparison with natural myo-inositol based substrates gave details and structural factors influencing binding of substrate to the enzymes. This study established that the absence of an axial hydroxyl/phosphate at the $\mathrm{C} 2$ position of an inositol phosphate reduces its potential as a substrate for IP6K1. In contrast, VIP1 appeared to accommodate the absence of an axial-2-phosphate more easily compared with IP6K1. All the scyllo-inositol derivatives tested are efficient in enhancing the ATPase activity of VIP1, which may be due to the preference of these compounds for the capture site on VIP1. Design of novel inhibitors based on these SAR studies and studies to identify the structures and biological effects of the products of these unnatural substrates are underway.

\section{Materials and Methods}

\subsection{General}

All chemicals and solvents were purchased from commercial suppliers and used directly. Solvents were dried using standard laboratory procedures and stored under anhydrous conditions. Reactions were monitored by thin layer chromatography (TLC) using Merck pre-coated silica plates (60 F254) (Darmstadt, Germany). TLC plates were visualized under ultraviolet light at $254 \mathrm{~nm}$ and also by charring using cerium ammonium molybdate solution ( $235 \mathrm{~mL}$ of distilled water, $12 \mathrm{~g}$ of ammonium molybdate, $0.5 \mathrm{~g}$ of cerium sulfate and $15 \mathrm{~mL}$ of concentrated sulphuric acid). Column chromatography was performed on silica gel (200-400 mesh). ${ }^{1} \mathrm{H},{ }^{19} \mathrm{~F},{ }^{13} \mathrm{C}$ and ${ }^{31} \mathrm{P}-\mathrm{NMR}$ spectra were recorded using 500, 470, 125 and 202.4 MHz NMR spectrometers (Bruker, Mannheim, Germany), respectively. Proton chemical shifts $(\delta)$ are relative to tetramethylsilane (TMS, $\delta=0.0$ ) as internal standard and expressed in parts per million (ppm). Spin multiplicities were given as $\mathrm{s}$ (singlet), d (doublet), $\mathrm{t}$ (triplet), (qt) quartet, dd (doublet of doublet), dt (doublet of triplet), 
ddd (doublet of doublet of doublet) and $\mathrm{m}$ (multiplet). Coupling constants (J) are given in Hertz $(\mathrm{Hz})$. The assignment of protons and carbons were done using two-dimensional spectroscopic techniques COSY, HMQC and HMBC. IR spectra were recorded using IR Prestige-21 (Shimadzu) spectrometer. Melting points were determined by using SMP-30 melting point apparatus (Stuart Scientific, Staffordshire, UK). Elemental analyses were done on Elementar, vario MICRO cube elemental analyzer (Elementar Americas, Ronkonkoma, NY, USA). Ion-exchange chromatography was performed on Biologic DuoFlow (Bio-Rad, Hercules, CA, USA) by using Q-Sepharose as Fast Flow resin, 2 M triethylammonium bicarbonate (TEAB) buffer and MilliQ water were used as gradient solvents. Phosphate analysis was done using Briggs and Ames phosphate assays. X-ray intensity data measurements of freshly grown crystals were carried out at 298K on a Bruker-KAPPA APEX II CCD (Bruker, Mannheim, Germany)diffractometer with graphite monochromatized (MoK $=0.71073 \AA$ ) radiation. The X-ray generator was operated at $50 \mathrm{kV}$ and $30 \mathrm{~mA}$. Data were collected with scan width of $0.3^{\circ}$ at different settings of $\varphi\left(0^{\circ}, 90^{\circ}\right.$ and $\left.180^{\circ}\right)$, keeping the sample to detector distance fixed at $40 \mathrm{~mm}$. The X-ray data collection was monitored by SMART program (Bruker, 2003) [64]. All the data were corrected for Lorentzian, polarization and absorption effects using SAINT and SADABS programs (Bruker, 2003). SHELX-97 was used for structure solution and full matrix least-squares refinement on F2 [65]. All the hydrogen atoms were placed in geometrically idealized position and refined in the riding model approximation with $\mathrm{C}-\mathrm{H}=0.95 \AA$, and with Uiso $(\mathrm{H})$ set to $1.2 \mathrm{Ueq}(\mathrm{C})$. Molecular diagrams were generated using ORTEP. Geometrical calculations were performed using SHELXTL (Bruker, 2003) and PLATON. Statistical analysis was performed using GraphPad Prism 5 (GraphPad Software, San Diego, CA, USA). Results are represented as mean \pm SEM. The differences between multiple groups were analyzed by one-way ANOVA, using Tukey's multiple comparison test. $p \leq 0.05$ is treated as statistically significant.

\subsection{Synthesis}

\subsubsection{Synthesis of Scyllo-Inositol (2)}

To a solution of compound 1 [45] ( $1 \mathrm{~g}, 2.33 \mathrm{mmol})$ in ethanol $(15 \mathrm{~mL}), 1 \mathrm{~N} \mathrm{HCl}$ solution $(5 \mathrm{~mL})$ was added and refluxed for $1 \mathrm{~h}$. After completion of the reaction, the reaction mass was filtered and the resultant solid was washed with DCM, and dried under reduced pressure, to get compound $2(0.3 \mathrm{~g}, 72 \%)$ as a white solid. ${ }^{1} \mathrm{H}-\mathrm{NMR}$ of compound $\mathbf{2}$ was identical with the reported data [46].

\subsubsection{Synthesis of 1,2,3,4,5,6-Hexakis-O-(dibenzyloxyphosphoryl)-Scyllo-Inositol (3)}

Dibenzyl $N, N$-diisopropylphosphoramidite $(2.3 \mathrm{~g}, 6.66 \mathrm{mmol})$ was added to a mixture of scyllo-inositol (2) (100 mg, $0.55 \mathrm{mmol})$ and $1 \mathrm{H}$-tetrazole $(0.46 \mathrm{~g}, 6.66 \mathrm{mmol})$ in acetonitrile $(10 \mathrm{~mL})$. The mixture was stirred for $15 \mathrm{~h}$ at room temperature. After $15 \mathrm{~h}$, temperature of the reaction mixture was cooled down to $-78^{\circ} \mathrm{C}$, then $m$-CPBA $(1.3 \mathrm{~g}, 8.3 \mathrm{mmol})$ was added and the reaction mixture was slowly warmed to room temperature. The reaction mass was extracted with ethyl acetate and washed successfully with sat. aq. $\mathrm{Na}_{2} \mathrm{SO}_{3}$, sat. aq. $\mathrm{NaHCO}_{3}$, water and brine. The organic layer was dried over anhydrous $\mathrm{Na}_{2} \mathrm{SO}_{4}$ and the solvent was evaporated under reduced pressure. The crude product thus obtained was purified by column chromatography using ethyl acetate and petroleum ether $(1: 1, v / v)$ as eluent, to get compound 3 (380 mg, $0.22 \mathrm{mmol}, 40 \%$ ) as sticky liquid. ${ }^{1} \mathrm{H}$ and ${ }^{31} \mathrm{P}-\mathrm{NMR}$ of compound 3 were identical with the reported data [46].

\subsubsection{Synthesis of Scyllo-Inositol Hexakisphosphate (4)}

To a solution of 1,2,3,4,5,6-hexakis-O-(dibenzyloxyphosphoryl)-scyllo-inositol (3) (320 mg, $0.18 \mathrm{mmol})$ in a mixture of $\mathrm{MeOH} / \mathrm{H}_{2} \mathrm{O}(2: 1, v / v, 10 \mathrm{~mL}), 10 \% \mathrm{Pd} / \mathrm{C}(100 \mathrm{mg})$ was added at room temperature and stirred under hydrogen atmosphere (using balloon) for $10 \mathrm{~h}$. After completion of the reaction, the reaction mass was filtered through a PTFE filter and the filtrate was concentrated under reduced pressure. Then, the residue was purified by ion-exchange chromatography on Q-sepharose Fast Flow resin eluting with a gradient of 
aqueous TEAB ( 0 to $1.0 \mathrm{M}$ ) to obtain the triethylammonium salt of scyllo-inositol hexakisphosphate $(4,104 \mathrm{mg}, 0.16 \mathrm{mmol}, 89 \%)$ as a white foamy solid. ${ }^{1} \mathrm{H}$ and ${ }^{31} \mathrm{P}-\mathrm{NMR}$ of the compound were identical with the reported data [46].

3.2.4. Synthesis of 6-O-Benzoyl-2,4-Di-O-(p-Methoxybenzyl)-1,3,5-O-MethylidyneScyllo-Inositol (5)

To a solution of compound $\mathbf{1}(1 \mathrm{~g}, 2.33 \mathrm{mmol})$ in dry pyridine $(20 \mathrm{~mL})$ at $0{ }^{\circ} \mathrm{C}$, benzoyl chloride $(0.4 \mathrm{~mL}, 3.48 \mathrm{mmol})$ and DMAP $(50 \mathrm{mg}, 0.41 \mathrm{mmol})$ were added and stirred for $4-5 \mathrm{~h}$. After completion of the reaction, water was added to quench the excess benzoyl chloride. The crude reaction mass was extracted with ethyl acetate and then washed thoroughly with saturated $\mathrm{NaHCO}_{3}$ solution, water and brine. The organic layer was dried over anhydrous $\mathrm{Na}_{2} \mathrm{SO}_{4}$ and the solvent was evaporated under reduced pressure. The crude product thus obtained was purified by column chromatography using ethyl acetate and petroleum ether $(2: 8, v / v)$ as eluent, to get compound $5(1.2 \mathrm{~g}, 96 \%)$ as a white solid. The m. p. $=92^{\circ} \mathrm{C}$; $\mathrm{RF}=0.7$ (ethyl acetate/petroleum ether, 3:7, v/v); 1H-NMR (500 MHz, $\left.\mathrm{CDCl}_{3}\right) \delta: 3.69(\mathrm{~s}, 6 \mathrm{H}$, $\left.2 \times \mathrm{OCH}_{3}\right), 4.31$ (brs, $\left.2 \mathrm{H}\right), 4.37\left(\mathrm{~d}, J=10.4 \mathrm{~Hz}, 2 \mathrm{H}, \mathrm{ArCH}_{2}\right), 4.48\left(\mathrm{~d}, J=10.4 \mathrm{~Hz}, 2 \mathrm{H}, \mathrm{ArCH}_{2}\right)$, 4.56 (brs, 3H), $5.52(\mathrm{~s}, 1 \mathrm{H}), 5.57$ (brs, $1 \mathrm{H}), 6.59(\mathrm{~d}, J=8.2 \mathrm{~Hz}, 4 \mathrm{H}, \mathrm{ArH}), 6.96-7.0(\mathrm{~m}, 6 \mathrm{H}, \mathrm{ArH})$, $7.33(\mathrm{t}, J=7.4 \mathrm{~Hz}, 1 \mathrm{H}, \mathrm{ArH}), 7.74(\mathrm{~d}, J=7.7 \mathrm{~Hz}, 2 \mathrm{H}, \mathrm{ArH}) .13 \mathrm{C}-\mathrm{NMR}\left(\mathrm{CDCl}_{3}, 125 \mathrm{MHz}\right)$ $\delta: 55.2,66.6,67.9,68.4,71.6\left(\mathrm{ArCH}_{2}\right), 72.7,103.1,113.6,128.0,128.5,129.5,129.6,129.62$, 130.2, 130.3, 132.8, 159.1, 166.1. Elemental analysis Calcd for $\mathrm{C}_{30} \mathrm{H}_{30} \mathrm{O}_{9}: \mathrm{C}, 67.41 ; \mathrm{H}, 5.66$. Found C, 67.23; H, 5.75.

\subsubsection{Synthesis of 1-O-Benzoyl-Scyllo-Inositol (6)}

To a solution of compound $5(1.0 \mathrm{~g}, 1.87 \mathrm{mmol})$ in ethanol $(15 \mathrm{~mL}), 1 \mathrm{~N} \mathrm{HCl}(5 \mathrm{~mL})$ was added and refluxed for $1 \mathrm{~h}$. After completion of the reaction, the reaction mass was filtered and the obtained solid was washed with DCM and dried under reduced pressure to get compound 6 as a white solid $(0.42 \mathrm{~g}, 79 \%) .{ }^{1} \mathrm{H}-\mathrm{NMR}$ of compound 6 was identical with the reported data [46].

3.2.6. Synthesis of 6-O-Benzoyl-1,2,3,4,5-Pentakis-O-(Dibenzyloxyphosphoryl)Scyllo-Inositol (7)

Dibenzyl $\mathrm{N}, \mathrm{N}$-diisopropylphosphoramidite $(0.49 \mathrm{~g}, 1.41 \mathrm{mmol})$ was added to a mixture of 1-O-benzoy-scyllo-inositol (6) $(40 \mathrm{mg}, 0.14 \mathrm{mmol})$ and $1 \mathrm{H}$-tetrazole $(99 \mathrm{mg}, 1.41 \mathrm{mmol})$ in dry acetonitrile $(10 \mathrm{~mL})$. The mixture was stirred for $15 \mathrm{~h}$ at room temperature. After $15 \mathrm{~h}$, temperature of the reaction mixture was cooled down to $-78{ }^{\circ} \mathrm{C}$, then $m$-CPBA $(60 \%, 0.33 \mathrm{~g}, 2.1 \mathrm{mmol})$ was added and the reaction mixture was slowly warmed to room temperature. The reaction mass was extracted with ethyl acetate and washed successfully with sat. aq. $\mathrm{Na}_{2} \mathrm{SO}_{3}$, sat. aq. $\mathrm{NaHCO}_{3}$, water and brine. The organic layer was dried over anhydrous $\mathrm{Na}_{2} \mathrm{SO}_{4}$ and the solvent was evaporated under reduced pressure. The crude product thus obtained was purified by column chromatography using ethyl acetate and petroleum ether $(1: 1, v / v)$ as eluent, to get compound $7(0.2 \mathrm{~g}, 0.13 \mathrm{mmol}, 93 \%)$ as a sticky liquid; ${ }^{1} \mathrm{H}-\mathrm{NMR}\left(500 \mathrm{MHz}, \mathrm{CDCl}_{3}\right) \delta: 4.46\left(\mathrm{dd}, J=9.3 \mathrm{~Hz}, 11.7 \mathrm{~Hz}, 2 \mathrm{H}, \mathrm{ArCH}_{2}\right)$, $4.67(\mathrm{~d}, J=7.4 \mathrm{~Hz}, 1 \mathrm{H}, \operatorname{ArCHA}), 4.70(\mathrm{~d}, J=7.4 \mathrm{~Hz}, 1 \mathrm{H}, \operatorname{ArCHB}), 4.74(\mathrm{~d}, J=8.1 \mathrm{~Hz}, 1 \mathrm{H}$, ArCHA), $4.76(\mathrm{~d}, J=8.1 \mathrm{~Hz}, 1 \mathrm{H}, \mathrm{ArCHB}), 5.01-4.77\left(\mathrm{~m}, 19 \mathrm{H}, \mathrm{ArCH}_{2} \& \mathrm{H}-2, \mathrm{H}-3, \mathrm{H}-4, \mathrm{H}-5\right.$, $\mathrm{H}-6), 5.69(\mathrm{t}, J=7.6 \mathrm{~Hz}, 1 \mathrm{H}, \mathrm{H}-1), 6.85(\mathrm{~m}, 4 \mathrm{H}, \mathrm{ArH}), 6.98(\mathrm{~m}, 4 \mathrm{H}, \mathrm{ArH}), 7.05-7.23(\mathrm{~m}, 42 \mathrm{H}$, $\operatorname{ArH}), 7.23(\mathrm{t}, J=7.9 \mathrm{~Hz}, 1 \mathrm{H}, \operatorname{Ar} H), 7.42-7.38(\mathrm{td}, J=1.2 \mathrm{~Hz}, 7.5 \mathrm{~Hz}, 1 \mathrm{H}, \operatorname{ArH}), 7.98(\mathrm{dd}$, $J=1.2 \mathrm{~Hz}, 8.3 \mathrm{~Hz}, 1 \mathrm{H}, \mathrm{ArH}) .{ }^{13} \mathrm{C}-\mathrm{NMR}\left(\mathrm{CDCl}_{3}, 125 \mathrm{MHz}\right) \delta: 69.4,69.5,69.6,69.7,69.9,69.92$, 69.97, 70.0, 70.04, 72.1, 75.9 ( ${ }^{31} \mathrm{P}$ coupled), $76.3\left({ }^{31} \mathrm{P}\right.$ coupled), 127.7, 127.9, 128.1, 128.15, $128.2,128.28,128.31,128.35,128.4,128.42,128.44,129.3,130.2,133.2,135.3,135.37,135.6$, 135.66, 135.7, 165.2. ${ }^{31} \mathrm{P}-\mathrm{NMR}\left(202.4 \mathrm{MHz}, \mathrm{CDCl}_{3}\right) \delta:-1.77$ (2P), -1.84 (3P). Elemental analysis Calcd for $\mathrm{C}_{83} \mathrm{H}_{81} \mathrm{O}_{22} \mathrm{P}_{5}: \mathrm{C}, 62.88 ; \mathrm{H}, 5.15$. Found $\mathrm{C}, 62.76 ; \mathrm{H}, 5.32$.

\subsubsection{Synthesis of 6-O-Benzoyl-Scyllo-Inositol-1,2,3,4,5-Pentakisphosphate (8)}

To a solution of 6-O-benzoyl-1,2,3,4,5-pentakis-O-(dibenzyloxyphosphoryl)-scyllo-inositol (7) $(160 \mathrm{mg}, 0.1 \mathrm{mmol})$ in a mixture of $\mathrm{MeOH} / \mathrm{H}_{2} \mathrm{O}(2: 1, v / v, 15 \mathrm{~mL}), 10 \% \mathrm{Pd} / \mathrm{C}(50 \mathrm{mg})$ 
was added at room temperature and stirred under hydrogen atmosphere (using balloon) for $10 \mathrm{~h}$. After completion of the reaction, the reaction mass was filtered through a PTFE filter and the filtrate was concentrated under reduced pressure. Then the residue was purified by ion-exchange chromatography on Q-sepharose Fast Flow resin eluting with a gradient of aqueous TEAB $(0$ to $1.0 \mathrm{M})$ to obtain the triethylammonium salt of 1-O-benzoyl-scyllo-inositol-2,3,4,5,6-pentakisphosphate (8) (50 $\mathrm{mg}, 0.073 \mathrm{mmol}, 73 \%)$ as a white foam; ${ }^{1} \mathrm{H}-\mathrm{NMR}\left(500 \mathrm{MHz}, \mathrm{CDCl}_{3}\right) \delta: 4.44-4.36(\mathrm{~m}, 3 \mathrm{H}, \mathrm{H}-3, \mathrm{H}-4, \mathrm{H}-5), 4.51$ $(\mathrm{qt}, J=9.3 \mathrm{~Hz}, 2 \mathrm{H}, \mathrm{H}-2, \mathrm{H}-6), 5.53(\mathrm{t}, J=9.6 \mathrm{~Hz}, 1 \mathrm{H}, \mathrm{H}-1), 7.4(\mathrm{t}, J=7.4 \mathrm{~Hz}, 2 \mathrm{H}, \mathrm{ArH})$, $7.53(\mathrm{t}, J=7.5 \mathrm{~Hz}, 1 \mathrm{H}, \mathrm{ArH}), 7.95(\mathrm{t}, J=7.9 \mathrm{~Hz}, 2 \mathrm{H}, \mathrm{ArH}) .{ }^{13} \mathrm{C}-\mathrm{NMR}\left(\mathrm{CDCl}_{3}, 125 \mathrm{MHz}\right)$ 8: 71.8 (C-1), 75.3 (C-2, C-6), 76.3 (C-4), 76.4 (C-3, C-5), 128.5, 128.9, 129.8, 133.9, 167.7. ${ }^{31} \mathrm{P}-\mathrm{NMR}\left(202.4 \mathrm{MHz}, \mathrm{CDCl}_{3}\right)$ 8: 2.12 (1P), $1.91(2 \mathrm{P}), 1.61$ (2P). Elemental analysis Calcd for $\mathrm{C}_{13} \mathrm{H}_{21} \mathrm{O}_{22} \mathrm{P}_{5}: \mathrm{C}, 22.82 ; \mathrm{H}, 3.09$. Found $\mathrm{C}, 22.75 ; \mathrm{H}, 3.33$.

\subsubsection{Synthesis of Scyllo-Inositol-1,2,3,4,5-Pentakisphosphate (9)}

The $1 \mathrm{~N} \mathrm{LiOH} \mathrm{(5} \mathrm{mL)} \mathrm{was} \mathrm{added} \mathrm{to} \mathrm{6-O-benzoyl-scyllo-inositol-1,2,3,4,5-pentakisphosphate} \mathrm{(8)}$ (50 mg, $0.073 \mathrm{mmol}$ ) and heated at $80{ }^{\circ} \mathrm{C}$ for $3 \mathrm{~h}$. After completion of the reaction the reaction mass was passed through Dowex 50WX8-100 ( H+ form) and eluted with water. The filtrate was concentrated under reduced pressure to obtain compound 9 (34 mg, $0.058 \mathrm{mmol}, 80 \%$ ) as a sticky solid. ${ }^{1} \mathrm{H}$ and ${ }^{31} \mathrm{P}-\mathrm{NMR}$ of the compound were identical with the reported data [46].

\subsubsection{Synthesis of 1-O-p-Methoxybenzyl-3,4,5,6-Tetra-O-Benzoyl-Myo-Inositol (11)}

To a solution of 1,4,5,6-tetra-O-benzoyl-myo-inositol (10) [50] (7 g, $11.7 \mathrm{mmol})$ in dry acetonitrile $(150 \mathrm{~mL})$, dibutyltinoxide $(3.2 \mathrm{~g}, 12.87 \mathrm{mmol})$ and tetrabutylammonium bromide $(6.49 \mathrm{~g}, 17.6 \mathrm{mmol})$ were added at room temperature and the mixture was refluxed for $3-4 \mathrm{~h}$. The reaction mass was then brought to room temperature, $p$-methoxybenzylchloride $(2.76 \mathrm{~g}, 17.6 \mathrm{mmol})$ was added and heated at $60^{\circ} \mathrm{C}$ for $12 \mathrm{~h}$. After completion of the reaction, $\mathrm{Et}_{3} \mathrm{~N}(1.18 \mathrm{~g}, 23.4 \mathrm{mmol})$ was added and refluxed for $1 \mathrm{~h}$. Then the reaction mass was extracted with ethyl acetate, washed successively with sat. aq. $\mathrm{NaHCO}_{3}$ solution, water and brine. The organic layer was dried over anhydrous $\mathrm{Na}_{2} \mathrm{SO}_{4}$ and the solvent was evaporated under reduced pressure. The crude product thus obtained was purified by column chromatography using a mixture of ethyl acetate and petroleum ether $(3: 7, v / v)$ as eluent, to get compound $11(7.04 \mathrm{~g}, 9.82 \mathrm{mmol}, 84 \%)$ as a white solid. The m. p. $=188{ }^{\circ} \mathrm{C}$; $\mathrm{R}_{\mathrm{f}}=0.6$ (ethyl acetate/petroleum ether, $\left.3: 7, v / v\right) ;{ }^{1} \mathrm{H}-\mathrm{NMR}\left(500 \mathrm{MHz}, \mathrm{CDCl}_{3}\right) \delta: 2.73(\mathrm{~s}, 1 \mathrm{H}$, 2-OH), $3.67\left(\mathrm{~s}, 3 \mathrm{H}, \mathrm{OCH}_{3}\right), 3.82(\mathrm{dd}, J=2.2 \mathrm{~Hz}, 9.75 \mathrm{~Hz}, 1 \mathrm{H}, \mathrm{H}-1), 4.40(\mathrm{~d}, J=11.8 \mathrm{HZ}, 1 \mathrm{H}$, $\left.\mathrm{CH}_{2}\right), 4.58\left(\mathrm{~m}, 2 \mathrm{H}, \mathrm{ArCH}_{2} \& \mathrm{H}-2\right), 5.23(\mathrm{dd}, J=1.9 \mathrm{~Hz}, 10.3 \mathrm{~Hz}, 1 \mathrm{H}, \mathrm{H}-3), 5.70(\mathrm{t}, J=10 \mathrm{~Hz}$, $1 \mathrm{H}, \mathrm{H}-5), 5.98(\mathrm{t}, J=9.9 \mathrm{~Hz}, 1 \mathrm{H}, \mathrm{H}-6), 6.23(\mathrm{t}, J=10.2 \mathrm{~Hz}, 1 \mathrm{H}, \mathrm{H}-4), 6.59(\mathrm{~d}, J=6.6 \mathrm{~Hz}, 2 \mathrm{H}$, $\mathrm{ArH}$ of PMB), $7.0(\mathrm{~d}, J=8.5 \mathrm{~Hz}, 2 \mathrm{H}, \mathrm{ArH}$ of PMB), $7.21(\mathrm{~m}, 3 \mathrm{H}), 7.34-7.29(\mathrm{~m}, 7 \mathrm{H}), 7.47-7.43$ $(\mathrm{m}, 2 \mathrm{H}), 7.70(\mathrm{t}, J=7.6 \mathrm{~Hz}, 4 \mathrm{H}), 7.82(\mathrm{~d}, J=7.3 \mathrm{~Hz}, 2 \mathrm{H}), 7.93(\mathrm{~d}, J=7.3 \mathrm{~Hz}, 2 \mathrm{H}) .{ }^{13} \mathrm{C}-\mathrm{NMR}$ $\left(\mathrm{CDCl}_{3}, 125 \mathrm{MHz}\right)$ 8: 55.2, 67.4 (C-2), 69.8 (C-4), $71.2(\mathrm{C}-5), 71.3(\mathrm{C}-6), 71.9\left(\mathrm{ArCH}_{2}\right), 72.1$ (C-3), 76.3 (C-1), 113.9, 128.2, 128.3, 128.5, 128.7, 128.8, 129.0, 129.2, 129.5, 129.6, 129.72, 129.76, 129.8, 129.9, 133.0, 133.1, 133.2, 133.5, 159.6, 165.4, 165.5, 165.8, 166.0. Elemental analysis Calcd for $\mathrm{C}_{42} \mathrm{H}_{36} \mathrm{O}_{11}$ : C, 70.38; $\mathrm{H}, 5.06$. Found $\mathrm{C}, 70.49 ; \mathrm{H}, 4.82$.

3.2.10. Synthesis of 1-O-p-Methoxybenzyl-3,4,5,6-Tetra-O-Benzoyl-2-OTrifluoromethanesulfonyl-Myo-Inositol (12)

To a solution of 1-O-p-methoxybenzyl-3,4,5,6-tetra-O-benzoyl-myo-inositol (11) (7.0 g, $9.76 \mathrm{mmol})$ in a mixture of dry DCM $(50 \mathrm{~mL})$ and dry pyridine $(20 \mathrm{~mL})$, triflic anhydride $(5.51 \mathrm{~g}, 19.5 \mathrm{mmol})$ was added at $0{ }^{\circ} \mathrm{C}$. After completion of the reaction, reaction mass was extracted with DCM and the organic layer was washed successfully with sat. aq. $\mathrm{NaHCO}_{3}$, water and brine. The organic layer was dried over anhydrous $\mathrm{Na}_{2} \mathrm{SO}_{4}$ and the solvent was evaporated under reduced pressure. The crude product thus obtained was purified by column chromatography using a mixture of ethyl acetate and petroleum ether $(2: 8, v / v)$ as eluent, to get compound $12(5.38 \mathrm{~g}, 6.34 \mathrm{mmol}, 65 \%)$ as a white solid; m. p. $=126{ }^{\circ} \mathrm{C} ;{ }^{19} \mathrm{~F}$ 


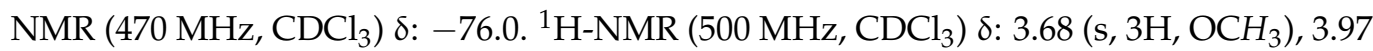
$(\mathrm{dd}, J=1.9 \mathrm{~Hz}, 10.2 \mathrm{~Hz}, 1 \mathrm{H}, \mathrm{H}-1), 4.34\left(\mathrm{~d}, J=12.2 \mathrm{~Hz}, 1 \mathrm{H}, \mathrm{ArCH}_{\mathrm{A}}\right), 4.70(\mathrm{~d}, J=12.2 \mathrm{~Hz}, 1 \mathrm{H}$, $\left.\mathrm{ArCH}_{\mathrm{B}}\right), 5.44(\mathrm{dd}, J=2.1 \mathrm{~Hz}, 10.5 \mathrm{~Hz}, 1 \mathrm{H}, \mathrm{H}-3), 5.59$ (brs, $\left.1 \mathrm{H}, \mathrm{H}-2\right), 5.72(\mathrm{t}, J=10.1 \mathrm{~Hz}, 1 \mathrm{H}$, H-5), 5.89 (t, $J=10.1 \mathrm{~Hz}, 1 \mathrm{H}, \mathrm{H}-6), 6.09$ (t, $J=10.27 \mathrm{~Hz}, 1 \mathrm{H}, \mathrm{H}-4), 6.58$ (d, J = 8.5 Hz, 2H, ArH of PMB), $7.0(\mathrm{~d}, J=8.5 \mathrm{~Hz}, 2 \mathrm{H}, \mathrm{ArH}$ of PMB), 7.17-7.21 (m, 1H), 7.29-7.35 (m, 8H), 7.47 $(\mathrm{m}, 3 \mathrm{H}), 7.73(\mathrm{t}, J=6.9 \mathrm{~Hz}, 4 \mathrm{H}), 7.78(\mathrm{~d}, J=7.3 \mathrm{~Hz}, 2 \mathrm{H}), 7.92(\mathrm{~d}, J=7.3 \mathrm{~Hz}, 2 \mathrm{H}) .{ }^{13} \mathrm{C}-\mathrm{NMR}$ $\left(\mathrm{CDCl}_{3}, 125 \mathrm{MHz}\right)$ 8: 55.0, 55.2, 69.2 (C-3), 69.3 (C-4), 70.1 (C-6), $70.6(\mathrm{C}-5), 72.0\left(\mathrm{ArCH}_{2}\right)$, 72.9 (C-1), 82.0 (C-2), 113.9, 127.8, 128.0, 128.3, 128.4, 128.5, 128.6, 129.1, 129.7, 129.8, 129.9, $130.0,130.1,133.3,133.36,133.4,134.0,159.7,164.9,165.1,165.6,165.7$. Elemental analysis Calcd. for $\mathrm{C}_{43} \mathrm{H}_{35} \mathrm{~F}_{3} \mathrm{O}_{13} \mathrm{~S}$ : C, 60.85; $\mathrm{H}, 4.16$. Found $\mathrm{C}, 60.68 ; \mathrm{H}, 4.11$.

3.2.11. Synthesis of 2-O-Acetyl-1-O-p-Methoxybenzyl-3,4,5,6-Tetra-O-BenzoylScyllo-Inositol (13)

To a solution of 1-O-p-methoxybenzyl-3,4,5,6-tetra-O-benzoyl-2-O-trifluoromethanesulfonylmyo-inositol (12) (5 g, $5.89 \mathrm{mmol})$ in $N, N$-dimethylacetamide $(30 \mathrm{~mL})$, potassium acetate $(2.89 \mathrm{~g}, 29.5 \mathrm{mmol})$ was added and heated at $70{ }^{\circ} \mathrm{C}$ for $2 \mathrm{~h}$. After completion of the reaction, the reaction mass was extracted with ethyl acetate and thoroughly washed with water and brine. The organic layer was dried over anhydrous $\mathrm{Na}_{2} \mathrm{SO}_{4}$ and the solvent was evaporated under reduced pressure. The crude product thus obtained was purified by column chromatography using a mixture of ethyl acetate and petroleum ether $(2: 8, v / v)$ as eluent, to get compound $13(4.25 \mathrm{~g}, 5.59 \mathrm{mmol}, 95 \%)$ as a white solid; m. p. $=254{ }^{\circ} \mathrm{C}$; ${ }^{1} \mathrm{H}-\mathrm{NMR}\left(500 \mathrm{MHz}_{\mathrm{CDCl}}\right) \delta: 1.83(\mathrm{~s}, 3 \mathrm{H}, \mathrm{OAc}), 3.64\left(\mathrm{~s}, 3 \mathrm{H}, \mathrm{OCH}_{3}\right), 3.99(\mathrm{t}, J=9.2 \mathrm{~Hz}, 1 \mathrm{H}$, $\mathrm{H}-1), 4.47\left(\mathrm{~d}, J=11.8 \mathrm{~Hz}, 1 \mathrm{H}, \mathrm{ArCH}_{\mathrm{A}}\right), 4.52\left(\mathrm{~d}, J=11.7 \mathrm{~Hz}, 1 \mathrm{H}, \mathrm{ArCH}_{\mathrm{B}}\right), 5.55(\mathrm{t}, J=9.7 \mathrm{~Hz}$, 1H, H-6), 5.65 (t, J = 9.7 Hz, 1H, H-5), 5.82-5.71 (m, 3H, H-2, H-3, H-4), 6.59 (d, J = 8.5 Hz, 2H, ArH of PMB), $6.96(\mathrm{~d}, J=8.5 \mathrm{~Hz}, 2 \mathrm{H}, \mathrm{ArH}$ of PMB), 7.33-7.27 (m, 7H), 7.46-7.42 (m, 2H), $7.70(\mathrm{~d}, J=7.5 \mathrm{~Hz}, 4 \mathrm{H}), 7.82(\mathrm{t}, J=6.6 \mathrm{~Hz}, 4 \mathrm{H}) .{ }^{13} \mathrm{C}-\mathrm{NMR}\left(\mathrm{CDCl}_{3}, 125 \mathrm{MHz}\right) \delta: 20.6$, $55.2,70.6$ (C-2 or C-3 or C-4 or C-5), 70.7 (C-3 or C-4 or C-5 or C-2), 71.0 (C-4 or C-5 or C-2 or C-3), 71.9 (C-6), 72.2 (C-5 or C-2 or C-3 or C-4), $74.5\left(\mathrm{ArCH}_{2}\right), 77.2(\mathrm{C}-1), 113.7,128.2$, $128.3,128.4,128.5,128.6,128.7,129.1,129.2$, 129.7, 129.8, 129.9, 133.2, 133.3, 133.5, 159.3, $165.2,165.3,165.5,165.6,169.4$. Elemental analysis Calcd. for $\mathrm{C}_{44} \mathrm{H}_{38} \mathrm{O}_{12}$ : C, 69.65; $\mathrm{H}, 5.05$. Found $\mathrm{C}, 69.59 ; \mathrm{H}, 4.83$.

\subsubsection{Synthesis of 1-O-p-Methoxybenzyl-Scyllo-Inositol (14)}

To a solution of 2-O-acetyl-1-O-p-methoxybenzyl-3,4,5,6-tetra-O-benzoyl-scyllo-inositol ( $4.0 \mathrm{~g}, 5.27 \mathrm{mmol})$ in methanol $(50 \mathrm{~mL})$, sodium methoxide $(57 \mathrm{mg}, 1.05 \mathrm{mmol})$ was added and refluxed for $4 \mathrm{~h}$. After completion of the reaction, Dowex ${ }^{\circledR} 50 \mathrm{WX} 8 \mathrm{H}^{+}(1 \mathrm{~g})$ was added to the reaction mass and stirred at room temperature for $10 \mathrm{~min}$. Then, the mixture was filtered and the resin was washed with methanol. The combined filtrate was evaporated under reduced pressure to get the title compound 14 as a white solid $(1.55 \mathrm{~g}, 5.16 \mathrm{mmol}$, 98\%). Charred at $220{ }^{\circ} \mathrm{C}$ without melting; ${ }^{1} \mathrm{H}-\mathrm{NMR}\left(500 \mathrm{MHz}, \mathrm{CDCl}_{3}\right) \delta:$ 2.94-3.04 (m, $4 \mathrm{H}), 3.12-3.17(\mathrm{~m}, 2 \mathrm{H}), 3.73\left(\mathrm{~s}, 3 \mathrm{H}, \mathrm{OCH}_{3}\right), 4.69$ (s, 2H, $\left.\mathrm{ArCH}_{2}\right), 4.81$ (brs, 5H, OH), $6.86(\mathrm{~d}$, $J=8.5 \mathrm{~Hz}, 2 \mathrm{H}, \mathrm{ArH}), 7.33(\mathrm{~d}, J=8.5 \mathrm{~Hz}, 2 \mathrm{H}, \mathrm{ArH}) .{ }^{13} \mathrm{C}-\mathrm{NMR}\left(\mathrm{CDCl}_{3}, 125 \mathrm{MHz}\right) \delta: 55.5$, $73.7,74.4,74.5,74.8,83.3,113.7,129.6,132.2,158.8$. Elemental analysis Calcd for $\mathrm{C}_{14} \mathrm{H}_{20} \mathrm{O}_{7}$ : C, 55.99; H, 6.71. Found C, 55.82; H, 6.65.

3.2.13. Synthesis of 6-O-p-Methoxybenzyl-1,2,3,4,5-Pentakis-O-(Dibenzyloxyphosphoryl)Scyllo-Inositol (15)

Dibenzyl $N, N$-diisopropylphosphoramidite $(5.76 \mathrm{~g}, 16.7 \mathrm{mmol})$ was added to a solution of 1-O-p-methoxybenzyl-scyllo-inositol (14) $(0.5 \mathrm{~g}, 1.67 \mathrm{mmol})$ and $1 H$-tetrazole $(1.17 \mathrm{~g}$, $16.7 \mathrm{mmol})$ in dry acetonitrile $(30 \mathrm{~mL})$. The mixture was stirred for $15 \mathrm{~h}$ at room temperature. After $15 \mathrm{~h}$, the reaction mixture was cooled down to $-78{ }^{\circ} \mathrm{C}$, then $m$-CPBA $(3.92 \mathrm{~g}$, $25.05 \mathrm{mmol}$ ) was added and the reaction mixture was slowly warmed to room temperature. The reaction mass was extracted with ethyl acetate and washed successively with sat. aq. $\mathrm{Na}_{2} \mathrm{SO}_{3}$, sat. aq. $\mathrm{NaHCO}_{3}$, water and brine. The organic layer was dried over anhydrous $\mathrm{Na}_{2} \mathrm{SO}_{4}$ and the solvent was evaporated under reduced pressure. The crude product thus 
obtained was purified by column chromatography using a mixture of ethyl acetate and petroleum ether $(1: 1, v / v)$ as eluent, to get compound $15(2.4 \mathrm{~g}, 15.03 \mathrm{mmol}, 90 \%)$ as a sticky liquid. ${ }^{1} \mathrm{H}-\mathrm{NMR}\left(500 \mathrm{MHz}, \mathrm{CDCl}_{3}\right) \delta: 3.56\left(\mathrm{~s}, 3 \mathrm{H}, \mathrm{OCH}_{3}\right), 4.06(\mathrm{t}, J=4.5 \mathrm{~Hz}, 1 \mathrm{H}), 4.4$ (brs, $2 \mathrm{H}), 4.80-4.99(\mathrm{~m}, 25 \mathrm{H}), 6.56(\mathrm{~d}, J=8.5 \mathrm{~Hz}, 2 \mathrm{H}), 7.1-7.2(\mathrm{~m}, 52 \mathrm{H}) .{ }^{13} \mathrm{C}-\mathrm{NMR}\left(\mathrm{CDCl}_{3}\right.$, $125 \mathrm{MHz}) \delta$ : 55.1, 69.6, 69.7, 69.8, 69.9, 72.5, $76.9\left({ }^{31} \mathrm{P}\right.$ coupled), $77.3\left({ }^{31} \mathrm{P}\right.$ coupled), $79.3\left({ }^{31} \mathrm{P}\right.$ coupled), 113.6, 128.0, 128.1, 128.3, 128.4, 128.5, 129.3, 129.5, 135.57, 135.63, 135.65, 135.68, 135.7, 135.71, 135.73, 159.1. ${ }^{31} \mathrm{P}-\mathrm{NMR}\left(202.4 \mathrm{MHz}, \mathrm{CDCl}_{3}\right)$ 8: -1.9, -2.0. Elemental analysis Calcd for $\mathrm{C}_{84} \mathrm{H}_{85} \mathrm{O}_{22} \mathrm{P}_{5}$ : C, 63.00; $\mathrm{H}, 5.35$. Found $\mathrm{C}, 62.82 ; \mathrm{H}, 5.61$.

\subsubsection{Synthesis of 1,2,3,4,5-Pentakis-O-(Dibenzyloxyphosphoryl)-Scyllo-Inositol (16)}

To a solution of 6-O-p-methoxybenzyl-1,2,3,4,5-pentakis-O-(dibenzyloxyphosphoryl)scyllo-inositol (15) (1 g, $0.62 \mathrm{mmol})$ in anhydrous 1,2-dichloroethane (20 mL), DDQ (170.0 mg, $0.75 \mathrm{mmol}$ ) was added and heated at $60^{\circ} \mathrm{C}$ for $3-4 \mathrm{~h}$. After completion of the reaction, the reaction mass was concentrated under reduced pressure and the crude residue was purified by column chromatography using a mixture of ethyl acetate and petroleum ether $(1: 1, v / v)$ as eluent to get compound $16(670 \mathrm{mg}, 0.45 \mathrm{mmol}, 73 \%)$ as a white solid. The m. p. $=112{ }^{\circ} \mathrm{C}$; ${ }^{1} \mathrm{H}-\mathrm{NMR}\left(500 \mathrm{MHz}, \mathrm{CDCl}_{3}\right) \delta: 3.98(\mathrm{td}, J=2.5 \mathrm{~Hz}, 8.2 \mathrm{~Hz}, 1 \mathrm{H}, \mathrm{H}-1), 4.65(\mathrm{qt}, J=8.1 \mathrm{~Hz}$, 2H, H-2 \& H-6), 4.65 (m, 1H, H-4), 4.73 (qt, $J=7.8 \mathrm{~Hz}, 2 \mathrm{H}, \mathrm{H}-3$ \& H-5), 4.91-5.13 (m, $20 \mathrm{H}), 5.29(\mathrm{~d}, J=2.6 \mathrm{~Hz}, 1 \mathrm{H}, \mathrm{OH}-1), 7.15-7.29(\mathrm{~m}, 50 \mathrm{H}) .{ }^{13} \mathrm{C}-\mathrm{NMR}\left(\mathrm{CDCl}_{3}, 125 \mathrm{MHz}\right)$ $\delta: 69.64,69.68,69.72,69.77,69.85,69.89,69.96,70.01,70.05,70.09,72.4(\mathrm{C}-1), 75.4\left(\mathrm{C}-4,{ }^{31} \mathrm{P}\right.$ coupled), 75.9 (C-3 \& C-5, ${ }^{31} \mathrm{P}$ coupled), 79.1 (C-2 \& C-6, ${ }^{31} \mathrm{P}$ coupled), 127.9, 128.03, 128.07, $128.1,128.3,128.33,128.38,128.4,128.47,128.5,135.5,135.62,135.69,135.71,135.76,135.8$, 135.86. ${ }^{31} \mathrm{P}-\mathrm{NMR}\left(202.4 \mathrm{MHz}, \mathrm{CDCl}_{3}\right) \delta:-1.55,-1.50,-0.79$. Elemental analysis Calcd for $\mathrm{C}_{76} \mathrm{H}_{77} \mathrm{O}_{21} \mathrm{P}_{5}$ : C, 61.62; $\mathrm{H}, 5.24$. Found $\mathrm{C}, 61.85 ; \mathrm{H}, 4.87$.

\subsubsection{Crystal Data for $\mathbf{1 6}$}

CCDC No. 1946543 (Figure 7) Molecular formula $=\mathrm{C}_{76} \mathrm{H}_{77} \mathrm{O}_{21} \mathrm{P}_{5}$, Formula weight $=1481.23$, colorless blocks, $0.25 \times 0.20 \times 0.15 \mathrm{~mm}$, Triclinic, space group P-1, 12.9915(9), $\mathrm{b}=16.3817(11)$, $\mathrm{c}=19.4914(14) \AA, \mathrm{V}=3759.2(5) \AA^{3}, \mathrm{Z}=2, \mathrm{~T}=293(2) \mathrm{K}, 2 \theta \max =50.00^{\circ}, \mathrm{D}$ calc $\left(\mathrm{g} \mathrm{cm}^{-3}\right)=1.309$, $\mathrm{F}(000)=1552, \mu\left(\mathrm{mm}^{-1}\right)=0.194,55445$ reflections measured, 13192 unique reflections $\left(R_{\text {int }}=0.0907\right)$, multi-scan absorption correction, $T_{\min }=0.9530, T_{\max }=0.9714$, number of parameters $=847$, number of restraints $=396, \mathrm{GoF}=0.986, \mathrm{R} 1=0.0884, \mathrm{wR} 2=0.2343, \mathrm{R}$ indices based on 13192 reflections with $\mathrm{I}>2 \mathrm{~s}(\mathrm{I}) . \Delta \rho \max =0.555, \Delta \rho \min =-0.358\left(\mathrm{e} \AA^{-3}\right)$.

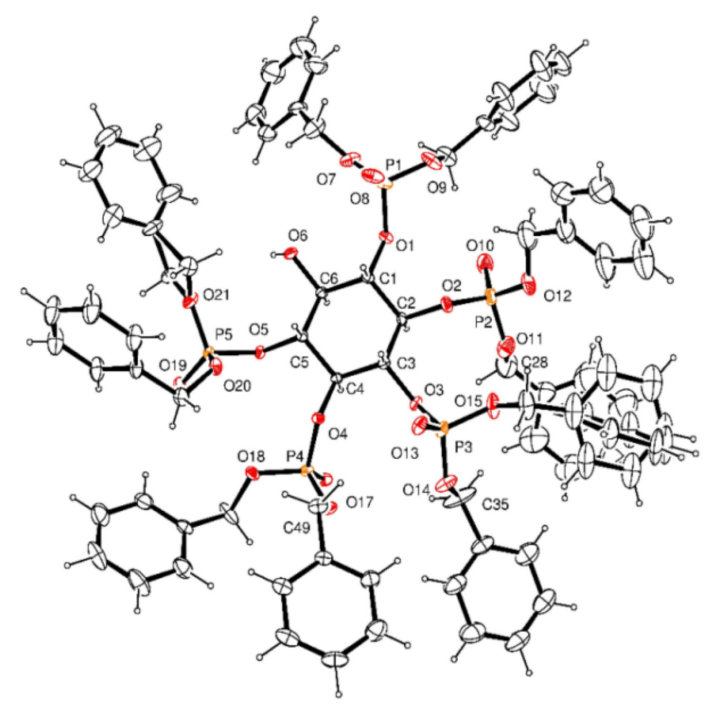

Figure 7. ORTEP diagram of compound $\mathbf{1 6}$ at $30 \%$ probability level. 
3.2.16. Synthesis of 2-Cyanoethyl- $N, N$-Diisopropylbenzylphosphoramidite

Diisopropylethylamine $(0.87 \mathrm{~mL}, 5.0 \mathrm{mmol})$ was added to a mixture of chloro-2-cyanoethyl- $N, N$-diisopropylphosphoramidite $(1.1 \mathrm{~mL}, 5.0 \mathrm{mmol})$ and benzyl alcohol $(0.52 \mathrm{~mL}, 5.0 \mathrm{mmol}$ ) at room temperature and stirred for $1 \mathrm{~h}$ (Scheme 3). The reaction mixture was extracted with $\mathrm{DCM}$, washed with sat. aq. $\mathrm{NaHCO}_{3}$ and the organic layer was dried over anhydrous $\mathrm{Na}_{2} \mathrm{SO}_{4}$. The organic layer was concentrated under reduced pressure and used without any further purification. ${ }^{1} \mathrm{H}$ and ${ }^{31} \mathrm{P}-\mathrm{NMR}$ of the compound (1.4 $\mathrm{g}, 4.54 \mathrm{mmol}, 91 \%)$ were identical with the reported data [66].

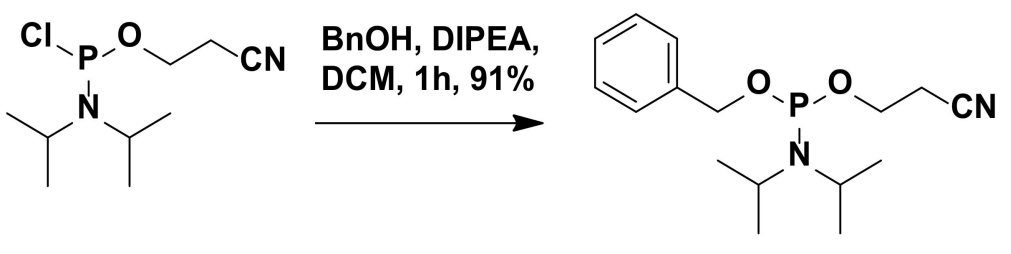

Scheme 3. Synthesis of 2-Cyanoethyl-N,N-Diisopropylbenzylphosphoramidite.

3.2.17. Synthesis of 6-((Benzyloxy)(2-Cyanoethoxy)Phosphoryl)-1,2,3,4,5-Pentakis-O(Dibenzyloxyphosphoryl)-Scyllo-Inositol (17)

To a solution of 1,2,3,4,5-pentakis-O-(dibenzyloxyphosphoryl)-scyllo-inositol (16) (0.2 g, $0.135 \mathrm{mmol})$ in dry DCM $(10 \mathrm{~mL})$, 2-cyanoethyl $\mathrm{N}, \mathrm{N}$-diisopropylbenzylphosphoramidite $(0.41 \mathrm{~g}, 1.35 \mathrm{mmol})$ and $1 \mathrm{H}$-tetrazole $(0.094 \mathrm{~g}, 1.35 \mathrm{mmol})$ were added. The mixture was stirred for $4 \mathrm{~h}$ at room temperature and then $m$-CPBA $(0.32 \mathrm{~g}, 2.03 \mathrm{mmol})$ was added at $-78{ }^{\circ} \mathrm{C}$ and the reaction mixture was slowly warmed to room temperature. The reaction mass was then extracted with ethyl acetate and washed successively with sat. aq. $\mathrm{Na}_{2} \mathrm{SO}_{3}$, sat. aq. $\mathrm{NaHCO}_{3}$, water and brine. The organic layer was dried over anhydrous $\mathrm{Na}_{2} \mathrm{SO}_{4}$ and the solvent was evaporated under reduced pressure. The crude product thus obtained was purified through column chromatography using a mixture of acetone and petroleum ether $(3: 7, v / v)$ as eluent, to get compound $17(160 \mathrm{mg}, 0.09 \mathrm{mmol}, 67 \%)$ as a sticky liquid; ${ }^{1} \mathrm{H}-\mathrm{NMR}\left(500 \mathrm{MHz}, \mathrm{CDCl}_{3}\right) \delta: 2.29(\mathrm{t}, J=6.4 \mathrm{~Hz}, 2 \mathrm{H}), 3.93(\mathrm{~m}, 2 \mathrm{H}), 4.87-5.08(\mathrm{~m}, 28 \mathrm{H})$, 7.12-7.20 (m, 55H). ${ }^{13} \mathrm{C}-\mathrm{NMR}\left(\mathrm{CDCl}_{3}, 125 \mathrm{MHz}\right) \delta: 62.4,62.5,69.9,70.0,70.1,70.3,70.4,76.3$, 76.4, 116.6, 128.0, 128.11, 128.19, 128.3, 128.5, 128.52, 128.6, 128.66, 128.7, 128.8, 135.2, 135.3, 135.52, 135.58. ${ }^{31} \mathrm{P}-\mathrm{NMR}\left(202.4 \mathrm{MHz}, \mathrm{CDCl}_{3}\right) \delta:-1.98,-2.78$. Elemental analysis Calcd for $\mathrm{C}_{86} \mathrm{H}_{87} \mathrm{NO}_{24} \mathrm{P}_{6}: \mathrm{C}, 60.60 ; \mathrm{H}, 5.14 ; \mathrm{N}, 0.82$. Found C, 60.53; H, 5.27; N. 0.88 .

3.2.18. Synthesis of 6-O-Benzyloxyphosphoryl-1,2,3,4,5-Pentakis-O-

(Dibenzyloxyphosphoryl)-Scyllo-Inositol (18)

To a solution of 6-((benzyloxy)(2-cyanoethoxy)phosphoryl)-1,2,3,4,5-pentakis-O(dibenzyloxyphosphoryl)-scyllo-inositol (17) $(0.1 \mathrm{~g}, 0.059 \mathrm{mmol})$ in dry acetonitrile $(1.0 \mathrm{~mL})$, DBU ( $35 \mu \mathrm{L}, 0.24 \mathrm{mmol}$ ) was added followed by the addition of bis(trimethylsilyl)trifluoroacetamide $(0.5 \mathrm{~mL})$ under nitrogen atmosphere. After $1 \mathrm{~h}$, the reaction mixture was filtered through Dowex $-\mathrm{H}^{+}$resin. The filtrate was concentrated under reduced pressure and the crude reaction mass was purified by column chromatography using methanol and dichloromethane $(1: 9, v / v)$ as eluent to afford compound $18(88 \mathrm{mg}, 0.053 \mathrm{mmol}, 90 \%)$ as a sticky solid; ${ }^{1} \mathrm{H}-\mathrm{NMR}$ [500 MHz, $\left.\mathrm{CDCl}_{3}: \mathrm{CD}_{3} \mathrm{OD}(3: 1)\right]$ 8: 1.61-1.70 (m, 5H), 2.48-2.50 (m, 2H), 3.31-3.37 $(\mathrm{m}, 4 \mathrm{H}), 3.75(\mathrm{~m}, 1 \mathrm{H}), 4.77-4.88(\mathrm{~m}, 24 \mathrm{H}), 4.93(\mathrm{~m}, 2 \mathrm{H}), 5.17(\mathrm{~m}, 2 \mathrm{H}), 6.99-7.13(\mathrm{~m}, 55 \mathrm{H})$. ${ }^{13} \mathrm{C}-\mathrm{NMR}\left(\mathrm{CDCl}_{3}: \mathrm{CD}_{3} \mathrm{OD}(3: 1), 125 \mathrm{MHz}\right)$ 8: 23.1, 26.5, 28.1, 29.7, 31.8, 36.1, 36.7, 45.3, 49.9, $67.6,67.7,69.8,69.9,69.98,70.0,70.2,70.3,70.36,70.4,74.7$ ( ${ }^{31} \mathrm{P}$ coupled), 76.8 ( ${ }^{31} \mathrm{P}$ coupled), 77.0 ( ${ }^{31} \mathrm{P}$ coupled), 77.5 ( ${ }^{31} \mathrm{P}$ coupled), 112.4, 114.6, 117.0, 119.2, 127.3, 127.4, 127.9, 127.98, 128.0, 128.1, 128.3, 128.4, 128.47, 134.9, 135.0, 135.07, 135.2, 135.22, 135.26, 137.5, 159.1, 159.4, 159.7, 159.8, 160.0, 177.9. ${ }^{31} \mathrm{P}-\mathrm{NMR}\left(202.4 \mathrm{MHz}, \mathrm{CDCl}_{3}\right)$ 8: $-1.92,-2.55,-3.03,-3.0$. Elemental analysis Calcd for $\mathrm{C}_{83} \mathrm{H}_{84} \mathrm{NO}_{24} \mathrm{P}_{6}$ : $\mathrm{C}, 60.37 ; \mathrm{H}, 5.13$. Found $\mathrm{C}, 60.31 ; \mathrm{H}, 5.19$. 
To a solution of 6-O-benzyloxyphosphoryl-1,2,3,4,5-pentakis-O-(dibenzyloxyphosphoryl)scyllo-inositol (18) (50 mg, $0.03 \mathrm{mmol})$ and trimethylamine $(9 \mu \mathrm{L}, 0.06 \mathrm{mmol})$ in anhydrous DCM, dibenzylphosphoryl chloride $(0.18 \mathrm{~mL}, 10 \%$ in toluene, $0.06 \mathrm{mmol})$ was added at $0{ }^{\circ} \mathrm{C}$. After $2 \mathrm{~h}$, the solvents were removed by applying vacuum, and the residue was completely dried at $10^{-2}$ mbar. The residue (19) was dissolved in $t-\mathrm{BuOH} / \mathrm{H}_{2} \mathrm{O}(6: 1, v / v$, $14 \mathrm{~mL})$ to which $10 \% \mathrm{Pd} / \mathrm{C}(100 \mathrm{mg})$ was added and stirred under hydrogen atmosphere (balloon pressure) for $10 \mathrm{~h}$. The catalyst was removed by filtration through a PTFE syringe filter and the filtrate was concentrated under reduced pressure. The obtained residue was purified by ion-exchange chromatography on Q-sepharose Fast Flow resin eluting with a gradient of triethylammonium bicarbonate (TEAB) buffer (0 to $2.0 \mathrm{M})$ and water to obtain the triethylammonium salt of $\mathbf{2 0}(10 \mathrm{mg}, 44 \%)$ as a white solid. ${ }^{31} \mathrm{P}-\mathrm{NMR}\left(202.4 \mathrm{MHz}, \mathrm{D}_{2} \mathrm{O}\right)$ $\delta: 1.99(5 \mathrm{P}),-6.1(1 \mathrm{P}),-11.0(1 \mathrm{P})$; HRMS (ESI) mass calculated for $\mathrm{C}_{6} \mathrm{H}_{19} \mathrm{O}_{27} \mathrm{P}_{7}[\mathrm{M}-\mathrm{H}]^{+}$, 738.8199 , found 738.5057 .

\subsection{Generation and Detection of PPIPn Products}

The 6xHis-tagged mouse IP6K1 (mIP6K1) and GST-tagged kinase domain of S. cerevisiae Vip1 (amino acid residues 1-535) (GST-VIP1-KD) were expressed and purified as described earlier [67]. Assays to detect synthesis of PPIP ${ }_{n}$ product were set up in reaction buffer ( $20 \mathrm{mM}$ Tris-Cl pH 7.4, $60 \mathrm{mM} \mathrm{NaCl}, 6 \mathrm{mM} \mathrm{MgCl}_{2}, 1 \mathrm{mM}$ DTT) in a $25 \mu \mathrm{L}$ reaction volume for PAGE analysis and a $50 \mu \mathrm{L}$ reaction volume for HPLC analysis. For PAGE analysis, the reactions were supplemented with $1 \mathrm{mM} \mathrm{Mg}^{2+}$-ATP, an ATP regeneration system ( $6 \mathrm{mM}$ phosphocreatine and $25 \mathrm{U} / \mathrm{mL}$ creatine phosphokinase), $\sim 1.2 \mu \mathrm{M}$ purified enzyme, and either $200 \mu \mathrm{M}$ IPn substrate (for 6xHis-IP6K1) or $100 \mu \mathrm{M}$ IPn substrate (for GST-VIP1 KD), and were incubated at $37^{\circ} \mathrm{C}$ for $18 \mathrm{~h}$. The reactions were mixed with $0.1 \%$ orange $\mathrm{G}$ containing loading dye and were resolved on a $35.8 \%$ polyacrylamide gel, overnight at $500 \mathrm{~V}$ in $1 \mathrm{X}$ TBE (Tris/borate/EDTA), as described earlier [52]. The gels were stained with $0.1 \%$ Toluidine blue $(w / v)$ in $20 \%$ methanol and $2 \%$ glycerol and were destained in $20 \%$ methanol and $2 \%$ glycerol. The gels were scanned on a desktop scanner (Laserjet M1136 MFP).

For HPLC analysis, the reactions were supplemented with $1 \mathrm{mM} \mathrm{Mg}{ }^{2+}$-ATP and $200 \mu \mathrm{M}$ IP $\mathrm{n}$ substrate for 6xHis-mIP6K1, and $40 \mu \mathrm{M} \mathrm{Mg}^{2+}$-ATP and $100 \mu \mathrm{M} \mathrm{IP}_{\mathrm{n}}$ substrate for GST-VIP1-KD. The concentration of ATP used in the assay was chosen on the basis of the reported affinities of IP6K1 and VIP1-kinase domain for ATP $(\mathrm{Km}$ value for ATP for mIP6K1 is $1.1 \mathrm{mM}$ [68]; Km value for ATP has not been measured for S. cerevisiae VIP1, but the kinase domain of human PPIP5K2 has a Km of 20-40 $\mu \mathrm{M}$ for ATP [38]. All reactions contained $2.5 \mu \mathrm{Ci}\left[\gamma^{-32} \mathrm{P}\right] \mathrm{ATP}$ (Regional Centre Hyderabad, BRIT, India) and $\sim 1.2 \mu \mathrm{M}$ purified enzyme, and were incubated at $37^{\circ} \mathrm{C}$ for $18 \mathrm{~h}$. A negative control was set up by incubating myo-IP ${ }_{6}$ in the presence of $\sim 1 \mu \mathrm{M} \mathrm{BSA}$, along with $2.5 \mu \mathrm{Ci}\left[\gamma^{3}{ }^{32} \mathrm{P}\right] \mathrm{ATP}$ and $40 \mu \mathrm{M} \mathrm{Mg}^{2+}$-ATP. The reactions were terminated by the addition of $40 \mu \mathrm{L}$ of $6 \mathrm{mM}$ EDTA, followed by $100 \mu \mathrm{L}$ of $0.6 \mathrm{M}$ perchloric acid, followed by $33 \mu \mathrm{L}$ neutralization solution (1 M potassium carbonate and $5 \mathrm{mM}$ EDTA). The inositol phosphates were resolved by HPLC (515 HPLC pumps, Waters) on a SAX Partisphere column (4.6 $\mathrm{mm}$ diameter and $125 \mathrm{~mm}$ length column, Whatman) using a gradient of buffer A (1 mM EDTA) and buffer B (1 mM EDTA and $\left.1.3 \mathrm{M}\left(\mathrm{NH}_{4}\right)_{2} \mathrm{HPO}_{4}, \mathrm{pH} 3.8\right)$ as follows: $0-5 \mathrm{~min}, 0 \% \mathrm{~B} ; 5-10 \mathrm{~min}$, 0-20\% B; 10-70 min, 20-100\% B; 70-80 min, 100\% B (see Supplementary Figure S2A for the elution gradient profile). One-milliliter fractions were mixed with $4 \mathrm{~mL}$ scintillation cocktail (Ultima-Flo AP, Perkin Elmer) and counted for $1 \mathrm{~min}$ in a liquid scintillation analyzer (Tri-Carb 2910 TR, Perkin Elmer). To identify the retention times for standard myo-IPs, we utilized radiolabelled inositol phosphates extracted from yeast strains harboring deletions of enzymes involved in inositol phosphate synthesis, as described earlier [69]. S. cerevisiae strain BY4741 wild type (WT), ipk1 $\Delta, k c s 1 \Delta$ and vip $1 \Delta$ were grown in synthetic medium containing yeast nitrogen base with ammonium sulphate and without inositol (MP Biomedicals), $2 \%$ dextrose (Sigma-Aldrich), $76 \mathrm{mg} / \mathrm{mL}$ uracil (HiMedia Laboratories), synthetic 
complete supplement mixture (SCSM; Formedium) without inositol, and supplemented with $5 \mu \mathrm{Ci} / \mathrm{mL}$ of $m y o-2-\left[{ }^{3} \mathrm{H}\right]$ inositol $(15-20 \mathrm{Ci} / \mathrm{mmol}$; American Radiolabeled Chemicals). The yeast was inoculated at $\mathrm{OD}_{600} 0.001$ and grown to $\mathrm{OD}_{600} \sim 1.0$ at $30^{\circ} \mathrm{C}$, harvested by centrifugation $(2000 \times g, 3 \mathrm{~min})$, lysed in $350 \mu \mathrm{L}$ chilled lysis buffer ( $1 \mathrm{M}$ perchloric acid, $0.2 \mathrm{mg} / \mathrm{mL} \mathrm{IP} 6,2 \mathrm{mM}$ EDTA) by bead beating using glass beads (Sigma-Aldrich). The soluble cell extracts were harvested by centrifugation $(21,000 \times g$ for $5 \mathrm{~min})$ and neutralized with $1 \mathrm{M}$ potassium carbonate $/ 5 \mathrm{mM}$ EDTA solution. The extracted inositol phosphates were resolved using the column and gradient described above. One-milliliter fractions were mixed with $3 \mathrm{~mL}$ scintillation cocktail and counted for $5 \mathrm{~min}$, as described above. In this way, we were able to identify the retention time for myo- $\mathrm{IP}_{5}, m y o-\mathrm{IP}_{6}, m y o-\mathrm{PP}_{\mathrm{IP}}$, $m y o-[\mathrm{PP}]_{2}-\mathrm{IP}_{3}, m y o-\mathrm{PP}-\mathrm{IP}_{5}$ and $m y o-[\mathrm{PP}]_{2}-\mathrm{IP}_{4}$, based on the IP profile described earlier for these strains [70] (Supplementary Figure S2B). The retention time of $\left[\gamma_{-}{ }^{32} \mathrm{P}\right] \mathrm{ATP}$, determined from the negative control reaction (see Supplementary Figure S2C), was found to be $\sim 20 \mathrm{~min}$. Therefore, to avoid any carryover of ATP, fractions collected from 35-70 $\mathrm{min}$ of the elution gradient were monitored to identify the $\mathrm{PPIP}_{\mathrm{n}}$ product. Minor variations in column back-pressure during consecutive HPLC runs led to inter-assay variations in retention time. However, the column was calibrated for each experimental set by making a note of the retention time of 5PP-myoIP 4 , the product of $m y o-\mathrm{IP}_{5}$ formed in the presence of IP6K1, and of $1 \mathrm{PP}-m y o-\mathrm{IP}_{5}$ and $5 \mathrm{PP}-m y o-\mathrm{IP}_{5}$, the products of $m y o-\mathrm{IP}_{6}$ formed in the presence of VIP1-KD and IP6K1, respectively, as indicated in Figure 2. The conversion of $\mathrm{IP}_{\mathrm{n}}$ substrate (10 nmoles and 5 nmoles respectively for IP6K1 and VIP1-KD reactions) to PPIP ${ }_{n}$ product (expressed in pmoles) was calculated based on the specific activity of ATP. All product peaks that were at least 5-fold above the baseline were counted. Data shown reflect the mean \pm S.E.M. from four independent assays, and were analyzed using GraphPad PRISM.

\subsection{Detection and Quantification of ATP Consumed and ADP Generated during the Kinase/ATPase Reaction}

To monitor ATP consumption by purified recombinant $6 \times$ His-mIP6K1 and GSTVIP1-KD, we used the ATPlite luminescence detection system (Perkin Elmer) as per the manufacturer's protocol. To rule out the possible co-purification of contaminating ATPases or phosphatases from the E. coli expression system, we used the generic ATPase inhibitor sodium orthovanadate $(2 \mathrm{mM})$, or a mixture of phosphatase inhibitors (Phosphatase Inhibitor Cocktail 3, Sigma-Aldrich P0044, used at the recommended concentration). The reactions were set up with $\sim 0.4 \mu \mathrm{M}$ 6xHis-mIP6K1 or $\sim 0.2 \mu \mathrm{M}$ GST-VIP1-KD in 1X reaction buffer (20 mM Tris-Cl pH 7.4, $60 \mathrm{mM} \mathrm{NaCl}, 6 \mathrm{mM} \mathrm{MgCl}$, and $1 \mathrm{mM} \mathrm{DTT}$ ) in a final volume of $25 \mu \mathrm{L}$. Bz-scyllo-IP 5 (200 $\mu \mathrm{M}$ for IP6K1 and $100 \mu \mathrm{M}$ for VIP1-KD) was used to stimulate the ATPase activity of the enzymes. The ATPase or phosphatase inhibitor, or a vehicle control, was added to the reaction for $15 \mathrm{~min}$ on ice, prior to the addition of ATP. The reactions were initiated by the addition of $40 \mu \mathrm{M} \mathrm{Mg}^{2+}$-ATP, incubated for $1 \mathrm{~h}$ at $37^{\circ} \mathrm{C}$ and suitably diluted for measurement of ATP. A standard curve was plotted with increasing amount of ATP and the luminescence values were extrapolated to obtain the amount of ATP remaining after the reaction was terminated. Data shown reflect the mean \pm range from two independent experiments and were analyzed using GraphPad PRISM.

The kinase/ATPase reactions for 6xHis-mIP6K1 and GST-VIP1-KD were set up in reaction buffer in a $10 \mu \mathrm{L}$ or $12.5 \mu \mathrm{L}$ reaction volume, respectively. The reactions were supplemented with $1 \mathrm{mM}$ ATP and $200 \mu \mathrm{M}$ IPn substrate for 6xHis-mIP6K1, and $40 \mu \mathrm{M}$ ATP and $100 \mu \mathrm{M}$ IPn substrate for GST-VIP1-KD, and $\sim 1.2 \mu \mathrm{M}$ purified enzyme. The final amount of ATP in the reaction was 10 nmoles and 500 pmoles, respectively, for IP6K1 and Vip1. Reactions were carried out for $18 \mathrm{~h}$ at $37^{\circ} \mathrm{C}$, cooled to $25^{\circ} \mathrm{C}$, and the amount of ADP generated was assayed using the ADP-GloTM kinase assay kit (Promega, Cat. \# V6930), according to the manufacturer's protocol. The ADP-GloTM kinase assay is a luminescence-based ADP detection method to measure the amount of ADP generated in the kinase reaction, and also reflects non-productive ATPase activity. After completion of the kinase/ATPase reaction, an equal volume of ADP-GloTM reagent was added and incubated at $25{ }^{\circ} \mathrm{C}$ for $30 \mathrm{~min}$ to terminate the reaction and to deplete the remaining ATP. 
The reaction mixture was transferred to a solid white 96-well plate, and double the volume of kinase detection reagent was added under dark, and incubated for $1 \mathrm{~h}$ to generate ATP from ADP, and measure the newly synthesized ATP using a luciferase/luciferin reaction. Luminescence was measured using a Multimode plate reader (EnSpire, Perkin Elmer, Waltham, MA, USA). The luminescence values were correlated with the percentage of ADP generated in the reaction by using an ATP-to-ADP standard curve. Appropriate volumes of ATP and ADP stock solutions were mixed to generate an ATP-to-ADP conversion standard curve. Separate standard curves were generated for IP6K1 and VIP1-KD—for IP6K1, $1 \mathrm{mM}$ ATP and ADP solutions were mixed to obtain a range of ADP from $0 \%$ to $10 \%$ of ATP; and for Vip1, $40 \mu \mathrm{M}$ ATP and ADP solutions were mixed to obtain a range of ADP from $0 \%$ to $40 \%$ of ATP. In every sample used for the standard curve, we included $1 \mathrm{X}$ reaction buffer and $100 \mu \mathrm{M}$ or $200 \mu \mathrm{M}$ IP6 respectively for VIP1-KD or IP6K1 assays, to account for any effects of buffer components or IPns on the luminescence reading. Standard curves were plotted and data was interpolated from three independent assays each for IP6K1 and VIP1-KD. Data shown reflect the mean \pm S.E.M. from three independent assays, and were analyzed using GraphPad PRISM.

As shown in Figure 5, we observed significant basal ATPase activity without the addition of IPn substrate, especially in the case of VIP1-KD. The graphs shown in Figure 6 clearly depict the percentage ADP generated in the presence of IPn substrate, after subtracting the amount of ADP generated in the absence of substrate.

Supplementary Materials: The following are available online, Section S1. PAGE analysis of PPIPn products; Section S2. Calibration of SAX HPLC for resolution of IPs and PPIPs; Section S3. Molecular Docking; Section S4. Effect of inhibitors on ATPase activity of IP kinases; Section S5. Spectral data. References [52,69-75] are cited in the Supplementary Materials.

Author Contributions: Conceptualization, K.M.S. and R.B.; synthesis and characterization compounds, R.M. (Raja Mohanrao); biochemical assays, R.M. (Ruth Manorama) and S.G.; molecular docking, M.C.M.; preparation of the manuscript, R.M. (Raja Mohanrao), R.M. (Ruth Manorama), S.G., M.C.M., R.B. and K.M.S. All authors have read and agreed to the published version of the manuscript.

Funding: K.M.S. thanks the Department of Science and Technology, Govt. of India for a SwarnaJayanti Fellowship. R.B. acknowledges support from the Science and Engineering Research Board, Department of Science and Technology, Govt. of India (CRG/2019/002597); Department of Biotechnology, Govt. of India (BT/PR29960/BRB/10/1762/2019); and CDFD core funds.

Institutional Review Board Statement: Not applicable.

Informed Consent Statement: Not applicable.

Data Availability Statement: The data presented in this study are available in the Supplementary Materials.

Acknowledgments: R.B. thanks members of the Laboratory of Cell Signalling for their valuable feedback.

Conflicts of Interest: The authors declare no conflict of interest.

Sample Availability: Some of the samples are available in small quantities. This may be available for some time.

\section{References}

1. Irvine, R.F.; Schell, M.J. Back in the water: The return of the inositol phosphates. Nat. Rev. Mol. Cell Biol. 2001, 2, 327-338. [CrossRef] [PubMed]

2. Best, M.D.; Zhang, H.; Prestwich, G.D. Inositol polyphosphates, diphosphoinositol polyphosphates and phosphatidylinositol polyphosphate lipids: Structure, synthesis, and development of probes for studying biological activity. Nat. Prod. Rep. 2010, 27, 1403-1430. [CrossRef]

3. Wilson, M.; Livermore, T.M.; Saiardi, A. Inositol pyrophosphates: Between signalling and metabolism. Biochem. J. 2013, 452, 369-379. [CrossRef]

4. Bennett, M.; Onnebo, S.M.N.; Azevedo, C.; Saiardi, A. Inositol pyrophosphates: Metabolism and signaling. Cell. Mol. Life Sci. 2006, 63, 552-564. [CrossRef] [PubMed] 
5. Shah, A.; Ganguli, S.; Sen, J.; Bhandari, R. Inositol Pyrophosphates: Energetic, Omnipresent and Versatile Signalling Molecules. J. Indian Inst. Sci. 2017, 97, 23-40. [CrossRef]

6. Barker, C.J.; Illies, C.; Gaboardi, G.C.; Berggren, P.-O. Inositol pyrophosphates: Structure, enzymology and function. Cell. Mol. Life Sci. 2009, 66, 3851-3871. [CrossRef]

7. Shears, S.B.; Weaver, J.D.; Wang, H. Structural insight into inositol pyrophosphate turnover. Adv. Biol. Regul. 2013, 53, 19-27. [CrossRef] [PubMed]

8. Wang, H.; Gu, C.; Rolfes, R.J.; Jessen, H.J.; Shears, S.B. Structural and biochemical characterization of Siw14: A protein-tyrosine phosphatase fold that metabolizes inositol pyrophosphates. J. Biol. Chem. 2018, 293, 6905-6914. [CrossRef]

9. Auesukaree, C.; Tochio, H.; Shirakawa, M.; Kaneko, Y.; Harashima, S. Plc1p, Arg82p, and Kcs1p, Enzymes Involved in Inositol Pyrophosphate Synthesis, Are Essential for Phosphate Regulation and Polyphosphate Accumulation in Saccharomyces cerevisiae. J. Biol. Chem. 2005, 280, 25127-25133. [CrossRef]

10. Azevedo, C.; Szijgyarto, Z.; Saiardi, A. The signaling role of inositol hexakisphosphate kinases (IP6Ks). Adv. Enzym. Regul. 2011, 51, 74-82. [CrossRef] [PubMed]

11. Bhandari, R.; Chakraborty, A.; Snyder, S.H. Inositol Pyrophosphate Pyrotechnics. Cell Metab. 2007, 5, 321-323. [CrossRef] [PubMed]

12. Burton, A.; Hu, X.; Saiardi, A. Are inositol pyrophosphates signalling molecules? J. Cell. Physiol. 2009, 220, 8-15. [CrossRef]

13. Lin, H.; Fridy, P.C.; Ribeiro, A.A.; Choi, J.H.; Barma, D.K.; Vogel, G.; Falck, J.R.; Shears, S.B.; York, J.D.; Mayr, G.W. Structural analysis and detection of biological inositol pyrophosphates reveal that the family of VIP/diphosphoinositol pentakisphosphate kinases are 1/3-kinases. J. Biol. Chem. 2009, 284, 1863-1872. [CrossRef]

14. Majerus, P.W. A discrete signaling function for an inositol pyrophosphate. Sci. STKE 2007, 2007, pe72. [PubMed]

15. Mulugu, S.; Bai, W.; Fridy, P.; Bastidas, R.J.; Otto, J.C.; Dollins, D.E.; Haystead, T.A.; Ribeiro, A.A.; York, J.D. A Conserved Family of Enzymes That Phosphorylate Inositol Hexakisphosphate. Science 2007, 316, 106-109. [CrossRef] [PubMed]

16. Onnebo, S.M.N.; Saiardi, A. Inositol Pyrophosphates Get the Vip1 Treatment. Cell 2007, 129, 647-649. [CrossRef]

17. Wang, H.; Falck, J.R.; Hall, T.M.T.; Shears, S.B. Structural basis for an inositol pyrophosphate kinase surmounting phosphate crowding. Nat. Chem. Biol. 2011, 8, 111-116. [CrossRef] [PubMed]

18. Wundenberg, T.; Mayr, G.W. Synthesis and biological actions of diphosphoinositol phosphates (inositol pyrophosphates), regulators of cell homeostasis. Biol. Chem. 2012, 393, 979-998. [CrossRef]

19. Saiardi, A. Cell Signalling by Inositol Pyrophosphates. Prokaryotic Cytoskelet. 2012, 59, 413-443. [CrossRef]

20. Tusi, M.M.; York, J.D. Roles of inositol phosphates and inositol pyrophosphates in development, cell signaling and nuclear processes. Adv. Enzyme Regul. 2010, 50, 324-337.

21. Thota, S.G.; Bhandari, R. The emerging roles of inositol pyrophosphates in eukaryotic cell physiology. J. Biosci. 2015, 40, 593-605. [CrossRef]

22. Brown, N.W., Jr.; Marmelstein, A.M.; Fiedler, D. Chemical tools for interrogating inositol pyrophosphate structure and function. Chem. Soc. Rev. 2016, 45, 6311-6326. [CrossRef] [PubMed]

23. Lee, Y.-S.; Huang, K.; Quiocho, F.A.; O'Shea, E.K. Molecular basis of cyclin-CDK-CKI regulation by reversible binding of an inositol pyrophosphate. Nat. Chem. Biol. 2008, 4, 25-32. [CrossRef] [PubMed]

24. Yin, M.-X.; Catimel, B.; Gregory, M.; Condron, M.; Kapp, E.; Holmes, A.B.; Burgess, A.W. Synthesis of an inositol hexakisphosphate (IP6) affinity probe to study the interactome from a colon cancer cell line. Integr. Biol. 2016, 8, 309-318. [CrossRef] [PubMed]

25. Lee, Y.-S.; Mulugu, S.; York, J.D.; O'Shea, E.K. Regulation of a Cyclin-CDK-CDK Inhibitor Complex by Inositol Pyrophosphates. Science 2007, 316, 109-112. [CrossRef]

26. Chakraborty, A.; Koldobskiy, M.A.; Bello, N.T.; Maxwell, M.; Potter, J.J.; Juluri, K.R.; Maag, D.; Kim, S.; Huang, A.S.; Dailey, M.J.; et al. Inositol pyrophosphates inhibit Akt signaling, thereby regulating insulin sensitivity and weight gain. Cell 2010, 143, 897-910. [CrossRef] [PubMed]

27. Luo, H.B.R.; Huang, Y.E.; Chen, J.M.C.; Saiardi, A.; Iijima, M.; Ye, K.Q.; Huang, Y.F.; Nagata, E.; Devreotes, P.; Snyder, S.H. Inositol pyrophosphates mediate chemotaxis in dictyostelium via pleckstrin homology domain-PtdIns(3,4,5)P3 interactions. Cell 2003, 114, 559. [CrossRef]

28. Albert, C.; Safrany, S.; Bembenek, E.M.; Reddy, K.M.; Falck, J.R.; Bröcker, M.; Shears, B.S.; Mayr, W.G. Biological variability in the structures of diphosphoinositol polyphosphates in Dictyostelium discoideum and mammalian cells. Biochem. J. 1997, 327, 553-560. [CrossRef]

29. Wu, M.; Dul, B.E.; Trevisan, A.J.; Fiedler, D. Synthesis and characterization of non-hydrolysable diphosphoinositol polyphosphate messengers. Chem. Sci. 2012, 4, 405-410. [CrossRef] [PubMed]

30. Zhang, H.; Thompson, J.; Prestwich, G.D. A Scalable Synthesis of the IP7 Isomer, 5-PP-Ins(1,2,3,4,6)P5. Org. Lett. 2009, 11, 1551-1554. [CrossRef]

31. Capolicchio, S.; Thakor, D.T.; Linden, A.; Jessen, H.J. Synthesis of Unsymmetric Diphospho-Inositol Polyphosphates. Angezw. Chem. Int. Ed. 2013, 52, 6912-6916. [CrossRef]

32. Capolicchio, S.; Wang, H.; Thakor, D.T.; Shears, S.B.; Jessen, H.J. Synthesis of Densely Phosphorylated Bis-1,5-Diphosphomyo-Inositol Tetrakisphosphate and its Enantiomer by Bidirectional P-Anhydride Formation. Angew. Chem. Int. Ed. 2014, 53, 9508-9511. [CrossRef] 
33. Pavlovic, I.; Thakor, D.T.; Bigler, L.; Wilson, M.; Laha, D.; Schaaf, G.; Saiardi, A.; Jessen, H.J. Prometabolites of 5-Diphospho-myoinositol Pentakisphosphate. Angew. Chem. Int. Ed. 2015, 54, 9622-9626. [CrossRef]

34. Pavlovic, I.; Thakor, D.T.; Vargas, J.R.; McKinlay, C.J.; Hauke, S.; Anstaett, P.; Camuña, R.C.; Bigler, L.; Gasser, G.; Schultz, C.; et al. Cellular delivery and photochemical release of a caged inositol-pyrophosphate induces $\mathrm{PH}$-domain translocation in cellulo. Nat. Commun. 2016, 7, 10622. [CrossRef]

35. Riley, A.M.; Wang, H.; Weaver, J.D.; Shears, S.B.; Potter, B.V.L. First synthetic analogues of diphosphoinositol polyphosphates: Interaction with PP-InsP5 kinase. Chem. Commun. 2012, 48, 11292-11294. [CrossRef]

36. Wu, M.; Chong, L.S.; Capolicchio, S.; Jessen, H.J.; Resnick, A.C.; Fiedler, D. Elucidating Diphosphoinositol Polyphosphate Function with Nonhydrolyzable Analogues. Angew. Chem. Int. Ed. 2014, 53, 7192-7197. [CrossRef] [PubMed]

37. Wu, M.; Chong, L.S.; Perlman, D.H.; Resnick, A.C.; Fiedler, D. Inositol polyphosphates intersect with signaling and metabolic networks via two distinct mechanisms. Proc. Natl. Acad. Sci. USA 2016, 113, E6757-E6765. [CrossRef] [PubMed]

38. Weaver, J.D.; Wang, H.; Shears, S.B. The kinetic properties of a human PPIP5K reveal that its kinase activities are protected against the consequences of a deteriorating cellular bioenergetic environment. Biosci. Rep. 2013, 33, e00022. [CrossRef] [PubMed]

39. Wang, H.; Godage, H.Y.; Riley, A.M.; Weaver, J.D.; Shears, S.B.; Potter, B.V.L. Synthetic Inositol Phosphate Analogs Reveal that PPIP5K2 Has a Surface-Mounted Substrate Capture Site that Is a Target for Drug Discovery. Chem. Biol. 2014, 21, 689-699. [CrossRef]

40. Shears, S.B.; Ali, N.; Craxton, A.; Bembenek, M.E. Synthesis and Metabolism of Bis-diphosphoinositol Tetrakisphosphate in Vitro and in Vivo. J. Biol. Chem. 1995, 270, 10489-10497. [CrossRef] [PubMed]

41. Craxton, A.; Caffrey, J.J.; Burkhart, W.; Safrany, S.; Shears, B.S. Molecular cloning and expression of a rat hepatic multiple inositol polyphosphate phosphatase. Biochem. J. 1997, 328, 75-81. [CrossRef]

42. Kilari, R.S.; Weaver, J.D.; Shears, S.B.; Safrany, S. Understanding inositol pyrophosphate metabolism and function: Kinetic characterization of the DIPPs. FEBS Lett. 2013, 587, 3464-3670. [CrossRef] [PubMed]

43. Wundenberg, T.; Grabinski, N.; Lin, H.; Mayr, G.W. Discovery of InsP6-kinases as InsP6-dephosphorylating enzymes provides a new mechanism of cytosolic InsP6 degradation driven by the cellular ATP/ADP ratio. Biochem. J. 2014, 462, 173-184. [CrossRef] [PubMed]

44. Dollins, D.E.; Bai, W.; Fridy, P.C.; Otto, J.C.; Neubauer, J.L.; Gattis, S.G.; Mehta, K.P.M.; York, J.D. Vip1 is a kinase and pyrophosphatase switch that regulates inositol diphosphate signaling. Proc. Natl. Acad. Sci. USA 2020, 117, 9356-9364. [CrossRef] [PubMed]

45. Riley, A.M.; Trusselle, M.; Kuad, P.; Borkovec, M.; Cho, J.; Choi, J.H.; Qian, X.; Shears, S.B.; Spiess, B.; Potter, B.V.L. scyllo -Inositol Pentakisphosphate as an Analogue of myo -Inositol 1,3,4,5,6-Pentakisphosphate: Chemical Synthesis, Physicochemistry and Biological Applications. ChemBioChem 2006, 7, 1114-1122. [CrossRef]

46. Chung, S.-K.; Kwon, Y.-U.; Chang, Y.-T.; Sohn, K.-H.; Shin, J.-H.; Park, K.-H.; Hong, B.-J.; Chung, I.-H. Synthesis of all possible regioisomers of scyllo-Inositol phosphate. Bioorganic Med. Chem. 1999, 7, 2577-2589. [CrossRef]

47. Kwon, Y.-U.; Im, J.; Choi, G.; Kim, Y.-S.; Choi, K.Y.; Chung, S.-K. Synthesis of three enantiomeric pairs of scyllo-inositol phosphate and molecular interactions between all possible regioisomers of scyllo-inositol phosphate and inositol 1,4,5-trisphosphate 3-kinase. Bioorganic Med. Chem. Lett. 2003, 13, 2981-2984. [CrossRef]

48. Thomas, M.P.; Mills, S.J.; Potter, B.V.L. The "Other" inositols and their phosphates: Synthesis, biology, and medicine (with recent advances in myo-inositol chemistry). Angew. Chem. Int. 2016, 55, 1614-1650. [CrossRef]

49. Turner, B.L.; Cheesman, A.W.; Godage, H.Y.; Riley, A.M.; Potter, B.V.L. Determination of neo- and d-chiro-Inositol Hexakisphosphate in Soils by Solution 31P NMR Spectroscopy. Environ. Sci. Technol. 2012, 46, 4994-5002. [CrossRef]

50. Sureshan, K.M.; Kiyosawa, Y.; Han, F.; Hyodo, S.; Uno, Y.; Watanabe, Y. Resolution of synthetically useful myo-inositol derivatives using the chiral auxiliary O-acetylmandelic acid. Tetrahedron Asymmetry 2005, 16, 231-241. [CrossRef]

51. Babouri, R.; Traore, L.; Bekro, Y.-A.; Matveeva, V.I.; Sadykova, Y.M.; Voronina, J.K.; Burilov, A.R.; Ayad, T.; Volle, J.-N.; Virieux, D.; et al. Golden Face of Phosphine: Cascade Reaction to Bridgehead Methanophosphocines by Intramolecular Double Hydroarylation. Org. Lett. 2018, 21, 45-49. [CrossRef] [PubMed]

52. Losito, O.; Szijgyarto, Z.; Resnick, A.C.; Saiardi, A. Inositol Pyrophosphates and Their Unique Metabolic Complexity: Analysis by Gel Electrophoresis. PLoS ONE 2009, 4, e5580. [CrossRef]

53. Draškovič, P.; Saiardi, A.; Bhandari, R.; Burton, A.; Ilc, G.; Kovačevič, M.; Snyder, S.H.; Podobnik, M. Inositol Hexakisphosphate Kinase Products Contain Diphosphate and Triphosphate Groups. Chem. Biol. 2008, 15, 274-286. [CrossRef] [PubMed]

54. Wang, H.; Derose, E.F.; London, R.E.; Shears, S.B. IP6K Structure and the Molecular Determinants of Catalytic Specificity in an Inositol Phosphate Kinase Family. Nat. Commun. 2014, 5, 4178. [CrossRef]

55. The PyMOL Molecular Graphics System, version 2.0 Schrodinger, LLC. Available online: https://pymol.org/2/support.html? \#citing (accessed on 9 June 2021).

56. Wormald, M.; Liao, G.; Kimos, M.; Barrow, J.; Wei, H. Development of a homogenous high-throughput assay for inositol hexakisphosphate kinase 1 activity. PLoS ONE 2017, 12, e0188852. [CrossRef] [PubMed]

57. Paudel, H.; Carlson, G. The ATPase activity of phosphorylase kinase is regulated in parallel with its protein kinase activity. J. Biol. Chem. 1991, 266, 16524-16529. [CrossRef]

58. Armstrong, R.N.; Kondo, H.; Kaiser, E.T. Cyclic AMP-dependent ATPase activity of bovine heart protein kinase. Proc. Natl. Acad. Sci. USA 1979, 76, 722-725. [CrossRef] 
59. Ward, N.E.; O'Brian, C.A. The intrinsic ATPase activity of protein kinase C is catalyzed at the active site of the enzyme. Biochemistry 1992, 31, 5905-5911. [CrossRef]

60. Ahmad, S.; Hughes, M.A.; Johnson, G.L.; Scott, J.E. Development and Validation of a High-Throughput Intrinsic ATPase Activity Assay for the Discovery of MEKK2 Inhibitors. J. Biomol. Screen. 2013, 18, 388-399. [CrossRef] [PubMed]

61. Fox, T.; Fitzgibbon, M.J.; Fleming, M.A.; Hsiao, H.-M.; Brummel, C.L.; Su, M.S.-S. Kinetic mechanism and ATP-binding site reactivity of p38gamma MAP kinase. FEBS Lett. 1999, 461, 323-328. [CrossRef]

62. Ferreira-Cerca, S.; Sagar, V.; Schaefer, T.; Diop, M.; Wesseling, A.-M.; Lu, H.; Chai, E.; Hurt, E.; LaRonde-LeBlanc, N. ATPasedependent role of the atypical kinase Rio2 on the evolving pre-40S ribosomal subunit. Nat. Struct. Mol. Biol. 2012, 19, 1316-1323. [CrossRef]

63. Trajtenberg, F.; Graña, M.; Ruétalo, N.; Botti, H.; Buschiazzo, A. Structural and Enzymatic Insights into the ATP Binding and Autophosphorylation Mechanism of a Sensor Histidine Kinase. J. Biol. Chem. 2010, 285, 24892-24903. [CrossRef] [PubMed]

64. Bruker. SADABS (Version 2.05), SMART (Version 5.631), SAINT (Version 6.45) and SHELXTL (Version 6.14); Bruker AXS Inc.: Madison, WI, USA, 2003.

65. Sheldrick, G.M. Crystal structure refinement with SHELXL. Acta Cryst. 2015, 71, 3-8.

66. Wang, X.J.; Xu, B.; Mullins, A.B.; Neiler, F.K.; Etzkorn, F.A. Conformationally locked isostere of phosphoSer-cis-pro inhibits pin1 23-fold better than phosphoSer-trans-pro isostere. J. Am. Chem. Soc. 2004, 126, 15533-15542. [CrossRef]

67. Bhandari, R.; Saiardi, A.; Ahmadibeni, Y.; Snowman, A.M.; Resnick, A.C.; Kristiansen, T.Z.; Molina, H.; Pandey, A.; Werner, J.K.; Juluri, K.R.; et al. Protein pyrophosphorylation by inositol pyrophosphates is a posttranslational event. Proc. Natl. Acad. Sci. USA 2007, 104, 15305-15310. [CrossRef]

68. Saiardi, A.; Erdjument-Bromage, H.; Snowman, A.M.; Tempst, P.; Snyder, S.H. Synthesis of diphosphoinositolpentakisphosphate by a newly identified family of higher inositol polyphosphate kinases. Curr. Biol. 1999, 9, 1323-1326. [CrossRef]

69. Azevedo, C.; Saiardi, A. Extraction and analysis of soluble inositol polyphosphates from yeast. Nat. Protoc. 2006, 1, $2416-2422$. [CrossRef] [PubMed]

70. Onnebo, S.M.N.; Saiardi, A. Inositol pyrophosphates modulate hydrogen peroxide signalling. Biochem. J. 2009, 423, 109-118. [CrossRef]

71. Jones, G.; Willett, P.; Glen, R.C.; Leach, A.R.; Taylor, R. Development and validation of a genetic algorithm for flexible docking. J. Mol. Biol. 1997, 267, 727-748. [CrossRef]

72. Dennington, R.; Keith, T.A.; Millam, J.M. GaussView, Version 6.1; Semichem Inc.: Shawnee Mission, KS, USA, 2016.

73. Avogadro: An Open-Source Molecular Builder and Visualization Tool. Version 1.2.0. Available online: http://avogadro.cc/ (accessed on 11 June 2021).

74. Riley, A.M.; Unterlass, J.; Konieczny, V.; Taylor, C.W.; Helleday, T.; Potter, B.V.L. A synthetic diphosphoinositol phosphate analogue of inositol trisphosphate. MedChem Comm 2018, 9, 1105-1113. [CrossRef]

75. Salentin, S.; Schreiber, S.; Haupt, V.J.; Adasme, M.F.; Schroeder, M. PLIP: Fully automated protein-ligand interaction profiler. Nucleic Acids Res. 2015, 43, W443-W447. [CrossRef] [PubMed] 